\title{
Registrované partnerství a homoparentalita v Česku'
}

\section{Zdeněk Sloboda}

\section{Registered Partnerships and LGBT Parenting in the Czech Republic}

\begin{abstract}
This paper introduces a unique and comprehensive sociological analysis of samesex partnerships in the Czech Republic, especially in the legally recognised (though limited) form of civil unions (registered partnerships - RP). The analysis combines multiple data sources and methodological approaches, drawing on administrative data from the Ministry of Internal Affairs $(n=2710)$, secondary quantitative data from the Czech Statistical Office and Public Opinion Research Centre/CVVM, and original quantitative $(n=882)$ and qualitative $(n=48)$ data. Focusing on the heteronormative framing of the issue, two main aspects come to the forefront: gender and LGBT parenting. Data show that there has been a small but steadily growing amount of interest in RP, especially among women, in the last six years. However, RP remains very selective and quite 'unpopular'. Although there has been a weakening of the procreative function of marriage, the role of RP in this respect is less clear-cut. On the one hand, it makes some paths to becoming a parent more difficult, while on the other, for some people, it provides a certain symbolic security for their existing family. The article also explores other gender and age characteristics and differences or similarities to marriage.
\end{abstract}

Keywords: registered partnership, LGBT parenting, same-sex couples, homosexuality, parenthood, LGBT+ rights

Sloboda, Zdeněk. 2021. Registrované partnerství a homoparentalita v Česku. Gender a výzkum / Gender and Research 22 (2): 139-169, http://dx.doi.org/10.13060/gav.2021.023.

1 Článek vznikl v rámci projektu Sociologického ústavu AV ČR, v.v.i. "Rodičovské tužby a intence gayů, leseb a bisexuálních mužů a žen v České republice" podpořeného GA ČR (reg. č. projektu: 18-07456S) a RVO: 68378025. 


\section{NV STATI / ARTICLES}

Zásadního sociálního a právního uznání se LGBT+ lidem v Česku dostává až po roce 1989. ${ }^{2}$ Kromě toho, že na začátku 90. let 20. století byla homosexualita vyškrtnuta jako nemoc a kriminalizace stejnopohlavního styku byla de facto zrušena, byly v roce 2006 (s platností od 1. června) na několikátý pokus právně uznány svazky párư stejného pohlaví (dále homopáry). Stalo se tak v podobě specifické zákonné úpravy, tzv. registrovaného partnerství (dále RP) odlišného od existujícího institutu párového soužití - manželství. Burešová (2020) uvádí, že jeden z prvních právních návrhů v mnoha aspektech odkazoval na paralelnost s manželstvím a nesl jen specifický název. Od takového institutu bylo postupně ustoupeno a schválený návrh zákona představoval ten nejméně podobný manželství. Partnerství vymezil jako status jiný (nikoliv rodinný), neobsahoval vdovské/vdovecké jistoty a také explicitně zakazoval individuální i párovou adopci (Burešová 2020). Přijetí tohoto návrhu bylo ústupkem tehdejších aktivistů a aktivistek, aby vůbec mohl být nějaký zákon prǐiat (Vráblíková 2006). Ani nový občanský zákoník v roce 2012, do nějž byl integrován zákon o rodině a všechny právní normy občanského práva, nepřinesl změnu, ač původně obsahoval tzv. zapsané partnerství pro páry stejného pohlaví. Z důvodu politické průchodnosti byl ale nakonec zachován status quo. Paradoxně tak zákon o RP upravující vztahy mezi občany nebyl zahrnut do nového komplexního občanského kodexu. Jedinou zásadnější změnu za uplynulých 15 let tedy učinil Ústavní soud, když v létě roku 2016 zrušil zákaz individuální adopce pro osoby v RP. Politicky neprošly tři návrhy

\footnotetext{
2 Ač se dekriminalizace homosexuálního kontaktu datuje do roku 1961, kdy byl novelizován trestní zákoník (Seidl 2012: 280-286).

3 Je třeba uvést, že používání pojmu „pohlaví" je problematické, jelikož odkazuje k biologickým charakteristikám a právnímu statusu, zatímco pojem "gender" k sociální (příp. psychické) situaci, a tudiž je rozhodně vhodnější při analýze sociálních jevů. $\vee$ textu se dopouštíme cisgenderové normativity, kdy se automaticky (a často mylně) předpokládá, že biologické či administrativní pohlaví determinuje genderové identity a role, které jsou v naší kultuře označovány jako mužské a ženské. Proto v tomto textu někdy synonymicky používáme pojmy "pohlaví" a "gender" nebo k pojmu "pohlaví" pojem "gender" priidáváme. Snažíme se tak poukázat na problematičnost pojmu pohlaví pro sociálněvědní analýzy. Bohužel dokud kvantitativní sociologické výzkumy nezavedou jinou než bipolární škálu a kategorii genderu (místo pohlaví, jež používají automaticky a standardně již desítky let), není možné v rámci práce $s$ daty pojem „pohlaví" neuvádět, jakkoliv je problematický. Proto se budeme vyhýbat v českém kontextu jazykově, společensky i právně nejčastěji používanému spojení "stejnopohlavní páry“ nebo „páry stejného pohlavi” (ač je přesnější než označení "homosexuální páry“, jelikož oba či obě z páru se nemusí identifikovat jako homosexuální). Rozhodli jsme se nevyužít občasně se vyskytující spojení „LGB páry” (lesbické, gay a bisexuální). Spojení "stejnogenderové páry“, které by se podle argumentu výše nabízelo, se v češtině nepoužívá. Takové použití by šlo proti uznávané konceptualizaci genderu jako nebinární charakteristiky a proti diskusi o variabilitě či fluiditě, a tudíž nestejnosti genderů dvou jedinců. Abychom se vyhnuli uvedeným problémům, zavádíme pojmy "homopáry" a "homopartnerství", jejichž utvoření je podobné jako u v textu používaného pojmu "homoparentalita”, jenž je v českém diskursu již vžitý (z toho důvodu nevolíme pojem "homorodičovství", který by se také nabízel).
} 
(z let 2013, 2014 a 2016) na umožnění adopce (tzv. přiosvojení) biologického dítěte druhým partnerem či druhou partnerkou (tzv. sociální rodič). Úspěšný nebyl ani pokus o otevření manželství homopárům předložený Poslanecké sněmovně PČR v roce 2017 (vše viz Burešová 2020).

Přesto, že v právním odůvodnění registrovaného partnerství z roku 2006 je upozorňováno na strukturální institucionalizovanou homofobii při neexistenci legalizované podoby svazku párů stejného pohlaví, je i samotná existence RP (s jeho nejméně 100 právními odlišnostmi od manželství) legalizací a institucionalizací homofobie - respektive heteronormativity (viz níže). Přičemž samozřejmě z nerovnosti partnerských vztahů vyplývají i nerovnosti v oblasti další, a tou je rodičovství.

V následujícím textu si klademe za cíl co nejkomplexněji představit RP v ČR, mezi lety 2006 a 2019, a to v souvislosti s heteronormativitou a jejími implikacemi nejen pro partnerství, ale také pro rodičovství. Naše snaha je značně limitována dostupností dat a jejich vypovídací schopností. Toto omezení je dáno především tím, že ze zákona pověřená statistická instituce - Český statistický úřad (ČSÚ) - systematicky data o RP nesbírá a nezveřejňuje. ${ }^{4} \vee$ textu tedy uvedeme především sekundární analýzu dat, která nebyla primárně sebrána za účelem sociologické analýzy. Kvantitativní datové zdroje v diskusi o rodičovství doplníme původními kvalitativními daty. Jelikož jde o první rozsáhlejší a sociologicky orientovaný text o podobě RP (a rodičovství) v průmětu bezmála 15 let jeho existence, jde o výzkum explorativního charakteru, jenž nezodpovídá konkrétní, z předchozích poznatků a teoretických předpokladů formulované hypotézy, ale naopak spíše hypotézy o různých souvislostech RP (např. s manželstvím) vyslovuje a nabízí je tak k budoucí analýze a ověření.

\section{Heteronormativita partnerských vztahů a rodičovství}

Normy - pravidla jednání - jsou základním konceptem nejen sociologie, ale i dalších disciplín, jako jsou ekonomie, právo či psychologie. Podle Jacka P. Gibbse se rozmanité konceptualizace norem sbíhají ve třech aspektech - jsou spojeny s kolektivním očekáváním, podléhají kolektivnímu hodnocení a předpokládají reakci na jednání, přičemž u velké části norem to bývá sankce (Gibbs 1965). Toto samožrejmě platíi pro oblast sexuality a intimity. $\vee$ pozdně moderní společnosti se sice (již několik dekád) významně proměňují intimní a partnerské vztahy (mj. Beck, Beck-Gernsheim 1995; Giddens 2012) směrem k větší rozvolněnosti, přesto normativní očekávání toho, co se

\footnotetext{
${ }^{4}$ To by se mělo dít od roku 2022, jelikož současný ředitel ČSú slíbil, že data o RP budou po Sčítání lidu v roce 2021 součástí tzv. malých cenzů. Viz vyjádření ze srpna 2020 citované např. zde: https://www. ceskenoviny.cz/zpravy/csu-povede-prubeznou-statistiku-o-registrovanych-partnerstvich/1909760
} 


\section{NV STATI / ARTICLES}

smí a nesmí a kdo tak může a nemůže činit, přetrvávají. Normativní očekávání a jím předepisované jednání můžeme nazvat normativitou.

Odlišení toho, co se (ne)smí, je formováno sociálními hodnotami, které jsou sdíleny v rámci společnosti či jednotlivých sociálních skupin a mají silnou historickou setrvačnost (viz např. Prudký a kol. 2009). Na sexualitu, intimitu a rodičovství je rovněž navázán určitý soubor hodnot, z nichž normy intimního, sexuálního, partnerského, resp. rodičovského chování vyplývají. Někteři autoři a autorky tento soubor hodnot, normativních očekávání, norem a způsobů jednání nazývají heteronormativita. Ta apriorně předpokládá heterosexualitu u všech jedinců od jejich narození a také ustrojuje společnost pro její správné naplňování. Heteronormativitu tvoří diskursivní, sociální, materiální i institucionální zpưsoby jednání a očekávání, jež odkazují k heterosexualitě jako k normě, přičemž všechno ostatní je odchylkou nebo narušením normy, a tak je marginalizováno, vyčleňováno či přehlíženo (mj. Warner 1991).

Podle Michaela S. Kimmela jsou významnými principy (hodnotami) heteronormativity: (a) misogynie (patriarchální nerovnost mezi muži a ženami; v kontextu homosexuality dopadá jinak na neheterosexuální muže a jinak na ženy), (b) bipolarizace (stavění heterosexuality a homosexuality do domnělých protipólů mající odlišné charakteristiky, ty připisované heterosexualitě jsou sociálně hodnotnější) a (c) esencializace (představa, že sexualita, obzvláště homosexualita, je pudová a že všechny negativní sociální aspekty homosexuality jsou přirozené a v zásadě neměnné) (Kimmel 2003). Institucionalizovaná heteronormativita má potom za důsledek nerovnost v legislativním ukotvení, ale i sociálním neuznání neheterosexuálního jednání nebo homopartnerství. Ve druhém př́padně se projevuje např. ve vytvoření institutu pro homopáry odlišného od toho pro páry "normální” (mj. Weeks 2000).

Heteronormativita není ale disciplinující jen k homosexualitě jako takové, ale ke všem sexuálním (a v důsledku genderovým) identitám a způsobưm chování, které se odchylují od stanovené normy. Normou je jen určitá podoba heterosexuality - párové soužití, ideálně autoritou uznané v manželství, kde muži a ženy mají „tradiční", komplementární genderové role a jejich vztah vede k naplnění v podobě početí a výchovy dětí (mj. Connell 1987). S marginalizací nebo stigmatizací se setkávají páry neplnící tuto funkci, tedy např. bezdětné (Hašková 2009; Slepičková 2014), narušující patriarchální podstatu, např. kde žena pracuje a muž pečuje o malé děti (Maříková 2009), kde je žena výrazně starší než muž, nebo vztahy polyamorické, jež narušují imperativ párovosti (a párové komplementarity muže a ženy).

$\checkmark$ ohledu rodičovství je homosexualita (a její životní styl) konstruována jako periferní a nedostatečná právě a především proto, že není schopna plodit potomky (Katz 2007) - myšleno „přirozeně” (za biologického přispění obou z páru). Přesto někteří autoři a autorky připisují rodičovství párů stejného pohlaví - homoparentalitě - silnou transformativní moc a všímají si pluralizace intimních vztahů a oslabování heteronor- 
mativity (Roseneil 2007). Postupnou sociální a právní akceptaci homosexuálního chování a partnerských vztahů vnímají jako emancipaci a proměnu heteronormativního rámce společnosti (Weeks 2000).

Nicméně podstata heteronormativity je hegemonní (např. Castro Varela et al. 2016) - "narušující" skupiny sice nejsou ze společnosti odstraňovány (jako dřive homosexualita byla), ale jsou tolerovány, pokud se snaží být co nejkonformnější a nejneviditelnějši. ${ }^{5}$ Důsledkem takového působení heteronormativity je úplné nebo jen částečné začleňování určité části dříve vylučované či marginalizované skupiny do "nové" normy, ovšem při současné produkci souhlasu "nové většiny" s novými nerovnostmi a s novým vyčleňováním jiných sociálních skupin. Tento princip spojený s parciálním přijetím (tolerancí) určité podoby homosexuality, pokud vykazuje žádoucí prvky heteronormativity, nazývá Lisa Duggan (2002) homonormativitou. Ta s sebou nese uznání té podoby životního stylu a identit gayů a leseb, které splňují normu párovosti a prokreativity - tedy rodičovství. Ovšem zároveň takto nastavená homonormativita marginalizuje, i prostřednictvím „těch nových dobrých" gayů a leseb, jiné neheterosexuální identity - bezdětné, hédonistické, singl, promiskuitní nebo genderově nekonformní či jinak queer. ${ }^{6}$ Naším zájmem je tudiž na základě dostupných dat nacházet podobnosti a specifičnosti mezi institucionalizovaným párovým soužitím RP a manželstvím a souvislosti s rodičovstvím.

\section{Zdroje dat a výzkumné otázky}

Na úvod je nutno konstatovat velký deficit $v$ dostupných datech a obzvláště $\checkmark$ jejich použití pro sociologicky orientovanou analýzu. Základní data o RP eviduje Ministerstvo vnitra. Statistiky o obyvatelstvu podle zákona (89/1995 Sb.) zpracovává a pravidelně zveřejňuje Čsú, který má i specifickou sekci tzv. genderových statistik. Nicméně statistiky o genderově "netypických" partnerstvích dvou mužů nebo dvou žen Čsú nezpracovává ani nezveřejňuje, protože nemá ze zákona (§ 12) výslovnou povinnost je zpracovávat ${ }^{7}$ na rozdíl od rozličných údajů o manželství a částečně i družství (nesezdaném soužití), a to i přesto, že podle stejného zákona (§ 9a) má $\mathrm{k}$ těmto datům explicitní přístup. ${ }^{8}$ Jediná data o RP zveřejnil ČSú jednorázově ve speciálním textu v roce 2014, kde prezentoval základní informace o věkové, vzdělanostní a rodičovské struktuře RP a vycházel ze stavu zachyceného ve Sčitání

\footnotetext{
${ }^{5}$ Nejlépe když v logice Foucaultova (2000) Panopticonu zneviditelňují samy sebe.

${ }^{6}$ Velice zjednodušeně queer označuje identity a praxe zásadně narušující normu (a normy) (mj. Warner 1991).

7 Podle e-mailu Marka Řezanky, který vede genderové statistiky na ČSú, z 5. 11. 2019.

8 Při přijímání nejspíše opomenutím nebylo RP vepsáno ani do textu $§ 12$, jenž vyjmenovává údaje, které má Čsú o obyvatelstvu zpracovávat a zveřejňovat.
} 


\section{NV STATI / ARTICLES}

lidu z roku 2011 (ČSú nedatováno/2014b), tedy již před deseti lety, po pěti letech existence RP. Systematické přehlížení RP státní statistickou autoritou je možné vnímat jako projev institucionalizované heteronormativity - RP pro ni stojí mimo normu zájmu - mimo heterosexuální párové vztahy a mimo "normální" charakteristiky obyvatelstva.

Kontinuální, leč velice bazální a dílčí údaje o RP z posledních čtrnácti let známe jen díky zájmu dvou soukromých osob, které jednou za půl roku kontaktují čtrnáct matrik, jež jsou zákonem pověřeny uzavíráním RP, a zaznamenané údaje dvakrát do roka poskytují zájemcům a zájemkyním, např. z médií. Tento neoficiální sběr uvádí počty uzavřených partnerství v jednotlivých krajích, pohlaví/gender párů a informace o cizincích a cizinkách vstupujících do RP. Data o ukončených partnerstvích nejsou úplná, jelikož některé matriční úrady tyto údaje nezaznamenávají. Zároveň data postrádají komplexitu a provázanost jednotlivých údajů. Dále z nich nevíme nic o věkové nebo vzdělanostní struktuře či dalších socioekonomických údajích nebo o délce trvání či důvodech zániku partnerství. Mnoho toho nevíme ani z těchto ani jiných dat o homoparentalitě - rodičovství gayů, leseb, resp. homopárů.

$\checkmark$ této studii proto představíme kombinaci kvantitativní a kvalitativní analýzy rưzných zdrojových dat, vč. výše uvedených. Základem studie je sekundární analýza dostupných administrativních dat o partnerstvích párů stejného pohlaví, především těch registrovaných. Budeme pracovat zejména s daty z databáze o obyvatelstvu ČR, která nám v dubnu 2020 na naši žádost jednorázově poskytlo Ministerstvo vnitra. Databáze, s nimiž MV ČR pracuje, nejsou uzpůsobeny pro statistické výstupy sociologického charakteru a z dưvodu ochrany osobních údajů nám byla data poskytnuta $\checkmark$ anonymizovaných dílčích datových souborech, čímž byla omezena možnost jejich propojování a statistické analýzy. $V$ datech chybí struktura RP geograficky či podle velikosti místa bydliště, podle výše vzdělání, prŕíjmu domácnosti nebo podle profese, což jsou standardní informace $u$ dat o obyvatelstvu, manželstvích nebo nesezdaných soužitích. Data ze systému MV je možné vygenerovat jen ve stavu $k$ určitému dni (zde k 31. 12. 2019), a tak sledovat vývoj či proměnu určitých charakteristik homopartnerství by bylo značně pracné. Proto se $z$ dat MV toho mnoho nedozvíme ani o již zaniklých partnerstvích.

Kromě sekundární analýzy těchto statistických dat zařadíme i sekundární analýzu statistických dat získávaných sociologickou výzkumnou agenturou CVVM v rámci jejích měsíčních omnibusových šetření na reprezentativním vzorku české populace.

Sekundární datové zdroje budou obzvláště v části o rodičovství doplněny o zjištění z pưvodního dotazníkového šetření zaměřeného na rodičovské touhy a intence gayů, leseb a bisexuálních žen a mužů realizovaného v roce 2019 na kvazireprezentativním vzorku české populace za použití on-line panelu, který se snažil vyhnout zkreslení $v$ důsledku výběru $\mathrm{LGB}(\mathrm{T})$ populace samovýběrem, což je charakteristické pro výzkumy 
na LGBT+ populaci. (Podrobněji viz Vohlídalová, Maříková v prrípravě.) ${ }^{9}$ Kvantitativní data byla analyzována v prostředí softwaru SPSS.

Pro získání většího vhledu do méně datově podložené oblasti homoparentality a také pro získání reflexe postavení RP a právního uznání vztahů mezi gayi, lesbami a bisexuálními muži a ženami budou dále použita data z pưvodního kvalitativního šetření - 48 hloubkových rozhovorů realizovaných v letech 2018-2020 v rámci projektu zkoumajícího rodičovské touhy a intence leseb, gayů a bisexuálních žen a mužů. Rozhovorů se zúčastnilo 28 žen a 22 mužů většinově se identifikujících jako gay či lesba, přičemž 20 z nich bylo rodiči. Data byla kódována nejprve volným kódováním v prostředí Atlas.ti a poté tematicky strukturována. Některé výpovědi týkající se motivací ke vstupu či nevstoupení do RP jsme zařadili do části "Vstup do RP" a výpovědi, které jsme kódovali jako rodičovství (ve vztahu k RP), se nacházejí v poslední analytické části "Ambivalentní RP a homoparentalita".

$\checkmark$ tomto textu budeme výše uvedená data analyzovat optikou heteronormativity. Zaměříme se na proměny vzniku, délky trvání a zániku RP ve srovnání s manželstvím. Budeme interpretovat aspekt genderu/pohlaví partnerů a partnerek, jelikož se podle dat jeví jako významný. Podíváme se na věkovou strukturu RP a vyjádříme možné implikace. Specificky se soustředíme na dosud právně neuznanou, leč reálně existující a v posledních několika letech značně zviditelňovanou homoparentalitu. Budeme diskutovat o tom, nakolik partnerství a rodičovství párů stejného pohlaví narušuje, transformuje či potvrzuje heteronormativní rámec české společnosti. Jelikož neexistuje na základě předchozích výzkumů dostatečná teoretická báze, z níž bychom mohli generovat hypotézy pro náš výzkum, je naše analýza explorativního charakteru a hypotézy o možných souvislostech spíše nastoluje pro budoucí výzkum. Výzkumnou otázku jsme formulovali takto: Co z dostupných dat víme o podobě a vývoji registrovaného partnerství $v$ ČR po 14 letech jeho existence a nakolik je možné $z$ dat usuzovat na narušování heteronormativity a vytváření homonormativity? V tomto kontextu bychom se chtěli vyjádřit prostřednictvím poznatků o charakteristikách, jako jsou: vznik, délka trvání, rozpad partnerství, pohlaví/gender a věk lidí v RP k tomu, nakolik je tento institut (ne)podobný manželství a zda je stabilizujícím či znejištujícím, nebo

\footnotetext{
9 Při tvorbě vzorku byla operacionalizována sexuální identita do dvou screeningových otázek. Kvótním výběrem byl osloven 25tisícový reprezentativní vzorek české populace ve věku 25-49 let (pro nějž bylo zkoumané téma rodičovství nejrelevantnější). Na základě screeningu bylo do vzorku pro studii rodičovských tužeb a intencí vybráno 796 osob. Kvůli překvapivě nízkému podílu lesbických žen byla realizována rekrutace na on-line panelu podruhé. Finální vzorek výzkumu čítá 882 osob, z toho 127 gayů, 29 leseb, 96 bisexuálních mužů, 177 bisexuálních žen, dále heterosexuálně sebeidentifikované muže ( $n$ $=95)$ a ženy $(n=319)$ a muže $(n=16)$ a ženy $(n=23)$, kteří svou sexualitu nijak neidentifikovali, ale kteř́ všichni deklarovali homosexuální zkušenosti či touhu v posledních pěti letech. Dotázaní vyplnili rozsáhlý dotazník zaměřený na rodičovské hodnoty a strategie.
} 


\section{NV STATI / ARTICLES}

přátelským či nepřátelským $\mathrm{k}$ rodičovství. I přes nedostatky datových zdrojů věříme, že představované poznatky vycházející z kombinace různých dat (vzniklých různými metodologickými přistupy) poskytnou nový a ojedinělý pohled na homopartnerství a homoparentalitu.

\section{Pozice RP v české společnosti}

Před tím, než se podíváme prostřednictvím dat „dovnitř" RP, považujeme za vhodné stručně nastínit pozici tohoto institutu v české společnosti. Ač je již od roku 2008 (po dvou letech své existence) institut RP českou společností vnímán jako žádoucí (75 \% populace), je případný coming-out (svěření se s homosexualitou svému okolí) považován za možný zdroj problémů až 42 \% české populace (CVVM 2019). Také $35 \%$ populace ČR souhlasí s tvrzením, že osoby v RP mají menší společenskou vážnost než osoby v manželství (CVVM 2020). Společenská podpora manželství pro homopáry se od roku 2014 pohybuje kolem 50 \%. Podpora přiosvojení vzrostla mezi lety 2014 a 2017 o deset procentních bodi̊, tj. na 68 \%, ale od té doby opět klesla. Plošší křivku vzestupu a poklesu zaznamenala podpora adopcí z institucionální péče (45\% až $51 \%$ ) (CVVM 2019).

Zatímco podpora RP je vysoká, ostatní údaje jsou ambivalentnější a indikují spíše toleranci (nikoliv akceptaci) nebo ignoraci (nikoliv inkluzi) gayů a leseb, resp. homopárů ze strany většinové populace. Tento jev dlouhodobě popisují mnohé autorky a autoři (Fojtová, Sokolová 2013; Guasti, Bustikova 2020; Nedbálková 2016; Sokolová 2009; Sloboda 2016). Na vnímání RP jako druhořadého institutu poukazovaly i situace, kdy v rámci opatření proti šíření pandemie covid-19 v roce 2020 bylo umožněno po určitou dobu uzavírat RP jen v ojedinělých případech (např. bližící se úmrtí nastávajíího partnera či partnerky), zatímco svatby byly povoleny jen s omezením počtu účastníků a účastnic. ${ }^{10}$

Jak právně, tak i společensky je možné vnímat institucionalizaci vztahu homopárů jako stabilizační prvek, i když neobsahuje zajištění v mnoha oblastech (Burešová 2020), neznemožňuje výkon rodičovských práv, či dokonce partnerce nebo partnerovi ukládá povinnost pečovat o př́padné dítě ve společné domácnosti. Přesto nepř́lišná ochota vstupovat do RP (obzvláště u žen) může znamenat, jak tvrdí Zdeněk Sloboda (2016), jistou neprátelskost tohoto institutu vůči rodičovství.

\footnotetext{
10 Např. zde: https://www.ceska-justice.cz/2020/11/vlada-zrusila-zakaz-uzavirat-registrovane-partnerstviosob-stejneho-pohlavi-kvuli-covid-19/
} 


\section{Vstup do registrovaného partnerství}

Vývoj počtu vznikajících registrovaných partnerství ukazuje, že po úvodním nadšení (v prvním roce a půl) zájem o vstup do RP klesal až na své minimum v roce 2011. Poté začal počet partnerství mírně stoupat, přičemž z roku 2015 (kdy se počet nově uzavřených partnerství opět dostal přes úvodní absolutní počty) na rok 2016 skokově narostl do historického maxima uzavřených partnerství v jednom roce. Od té doby spíše stagnuje. ${ }^{11}$

Graf 1: Počty vzniklých a zaniklých RP v jednotlivých letech

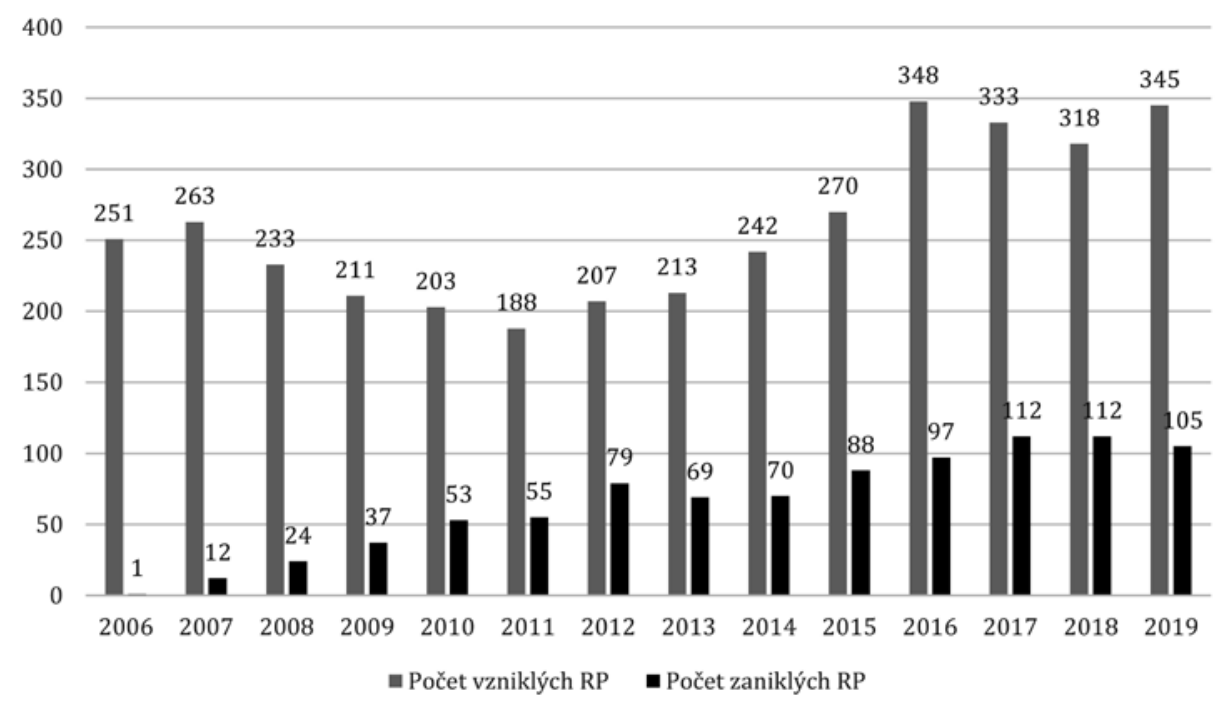

Zdroj: MV ČR, vlastní zpracování.

Nárůst nových RP se v posledních čtyřech letech drží nad počtem 300, což je nejvíce za dobu jeho existence. Opět $z$ dat ale není možné vyčíst důvod nárůstu počtu RP. Lze předpokládat několik příčin tohoto jevu. (1) Prvním důvodem může být početně silnější věková kohorta lidí ve věku 35-45 let, kteří do RP vstupují nejčastěji. (2) Při pohledu na propad sňatečnosti populace ve stejném období, je možné uvažovat např. o dopadu ekonomické krize. Další př́činy mohou být pro LGBT+ populaci specifické. (3) Čtrnáctileté období existence RP přispělo $k$ určité normalizaci pohledu na gaye, lesby a jejich vztahy. Zvyšování míry tolerance (CVVM 2019) a tím určité sní-

11 Pro rok 2020 je vzhledem k restrikcím v souvislosti s pandemií covid-19 možné počítat s výrazným poklesem vzniku nových partnerství. 


\section{NV STATI / ARTICLES}

žení společenské homofobie může zvýšit míru ochoty homopárů se zviditelnit právě vstupem do RP. (4) Nezanedbatelným vlivem může být zvýšená medializace mezi lety 2014 a 2017, která byla spojena se zviditelněním homoparentálních rodin a s legislativní snahou jak o zrušení zákazu adopcí v RP, tak především snahou umožnit tzv. přiosvojení. Toto může indikovat vzestup podpory přiosvojení mezi lety 2014 a 2017 o deset procentních bodů (CVVM 2019). Na druhou stranu mohly mediální viditelnost a požadavky na právní uznání homoparentality vést k polarizaci postojů, jež souvisejí i s rostoucí prítomností populismu ve veřejném prostoru (např. kampaň strany SPD ke sněmovním volbám v ř́ijnu 2017).

Důvody pro vstup do RP jsou rozmanité. Na základě analýzy bezmála padesáti vlastních kvalitativních rozhovorů jsme identifikovali několik typů argumentů pro vstup či nevstoupení. Odlišili jsme pozitivní a negativní argumenty, systémové a individuální a také instrumentálně nebo hodnotově orientované.

My jsme se prostě jenom chtěly vzít, a když nám nabídli „jenom” registrované partnerství, tak jsme si řekly (...), že lepší něco než nic. V roce 2007. (Luisa a Lotka, 36 a 45 let, lesba a bisexuálka, registrované, nerodiče)

V naší typologii bychom tento argument označili jako pozitivní, individuální a spíše hodnotový. Instrumentálnější pohled měl např́iklad Karel:

To je zase krok dvě. Kdyby to fungovalo hezky pár let v té společné domácnosti nebo nějak životně a oba dva jsme chtěli, tak si myslím, že pak to neni problém být registrovaný nebo provdaný za sebe. (Karel, 41 let, gay, singl, nerodič)

Většina argumentů ale přicházela v kombinaci:

To mě tedy registrované partnerství moc neoslovuje, že bych ho potřeboval uzavirat. Je to pro mě takový kočkopes $k$ ničemu, v uvozovkách. Co mi to přinese? Nic. Já ted' neříkám, že potřebuji, aby mi to něco príneslo, ale nic nezmění na pevnosti vztahu. (...) [Ale] jsem rád, že existuje, protože to je něco jako posun v uznání gayů, že existují nějaké gay svazky a podobně. Pro mě osobně, kdybychom se měli s mladým vzít nebo registrovat, to nedává smysl. Jediné, k čemu by to mělo smysl, že by mu to zjednodušilo trvalý pobyt. (Eduard, 40 let, gay, zadaný, nerodič)

První část Eduardovy výpovědi je především individuálně-instrumentální argumentace proti RP, zatímco druhá část přinášející systémově-hodnotový argument vidí tento institut jako pozitivní. Poslední větou ale Eduard nachází pozitivní individuálně- 
-instrumentální aspekt, a to proto, že jeho partner je cizinec. ${ }^{12}$ Obdobná argumentace individuální (a instrumentální) nepotřebnosti se objevovala typicky u informantů a informantek, kteří nebyli ve vztahu, jenž by považovali za vážný. Jedinci zpravidla angažovaní v aktivitách pro LGBT+ komunitu či liberálně smýšlející uváděli onen systémově-hodnotový argument.

Mně to prijjde ponižujicí, že to je jakoby takový patvar, taková úlitba, vlastně jako sňatek druhé jakosti. To bych raději zůstal svobodný, než bych do toho šel. Ted'jsem navštivil pár svateb, takže jsem z toho takový naměkko a dokážu si představit, že bychom se vzali. (...) A zároveň si to dovedu představit i bez dětí. Myslím si, že to není nutné, když se lidé vezmou, že musí mít děti. (Boris, 26 let, gay, singl, nerodič)

Podle některých se hodnotová, symbolická jinakost či nedostatečnost zrcadlí už jen v názvu. Klára (47 let, bisexuální, neregistrovaná, rodič dospělého) označení „registrovaná" vnímá jako stigma. Nejčastěji se ale objevuje argument, jaký uvedl David: "My nechceme dělat registrovaný partnerství, takové naše heslo je, že se registrují věci, a ne lidé." (David, 27 let, gay, zadaný, nerodič) Nutno ale zde podotknout, že není jisté, že toto je spontánní, vlastní označení. S argumentem „registrují se auta, ne lidé" pracuje již od roku 2018 kampaň za manželství Jsme fér!. Jde přitom spiše jen o marketingovou zkratku, jelikož existuje velké množství situací, kdy se lidé registrují, aktuálně např. do vakcinačního systému, ale rovněž do registru dárců a dárkyň krve, do e-shopů apod.

Trochu jiný př́stup měla lesbická matka Lara (39 let, lesba, zadaná, matka, předškolák), která také uváděla, že se jí slovo „registrovaný“ nelíbí („To je jako kdybyste registrovala někde nějaký krávy nebo skot."), ale partnerství pro páry stejného pohlaví by nerušila, zachovala by slovo manželství jen pro muže a ženu, aby to nedělalo ve společnosti zle, aby ji to nerozdělovalo, protože v důsledku jde o to, abychom měli primárně všichni stejná práva. Obdobně argumentoval Cyril, jenž sice viděl RP spiše negativně, ale zdůraznil nutnost okamžitě vyřešit situaci dětí v RP i za cenu toho, že

12 Pro doplnění obrazu o RP v Česku ještě uved'me, že zhruba 300 osob v existujících RP (k 31. 12. 2019) jsou cizinci. Cizince si nepatrně častěji berou muži než ženy. Téměř polovinu z toho tvoří Slováci a Slovenky, do RP dále vstupují Ukrajinci nebo Ukrajinky či osoby ze zemí mimo EU (např. USA, Brazílie, Indonésie nebo Dominikánské republiky). To může být způsobeno především tím, že ve velké části zemí EU je již povoleno manželství pro homopáry, a tak tyto smíšené páry volí uznání svého partnerství podle legislativy druhého státu. To ale může způsobovat problémy v symbolické rovině ["Chceme se vrátit do Čech. My jsme tady v Belgii v manželství, v Český republice jsme luznányl v registrovaným partnerství. Není to to samý." (Marta, 33 let, bisexuální, vdaná, sociální i biologický rodič)], ale i v instrumentální, tedy praktické rovině, např. při (ne)uznávání rodičovství obou z homopáru realizovaného v zahraničí (Hašková, Sloboda 2019; Burešová 2020). 


\section{STATI / ARTICLES}

zůstane pro homopartnerství jiný název. U těchto dvou, ale i několika dalších byla instrumentalita právní rovnosti nadřazena rovnosti hodnotové, což je projevem souhlasu s heteronormativitou.

\section{Zánik registrovaných partnerství}

Od poloviny roku 2006 do konce roku 2019 vstoupilo v Česku do registrovaného partnerství 3625 párů..$^{13}$ Ovšem pouze 2710 jich (k 31. 12. 2019) stále existovalo, jelikož 915 partnerství se za tuto dobu rozešlo, resp. bylo zrušeno. To představuje zhruba čtvrtinovou "rozvodovost" homopárů.

Jde zdánlivě o číslo zhruba poloviční ve srovnání s manželstvími. Pokud se ale podíváme na poměr uzavřených a zrušených RP z jednotlivých let (graf 2), tak se u partnerství vzniklých v prvních čtyřech letech (2006-2009) pohybuje míra "rozvodovosti“ mezi 40 a 50 \%, čímž se tato situace podobá míre rozvodovosti manželství.

Graf 2: Stále trvající a již zaniklá RP z příslušných let (stav k 31. 12. 2019)

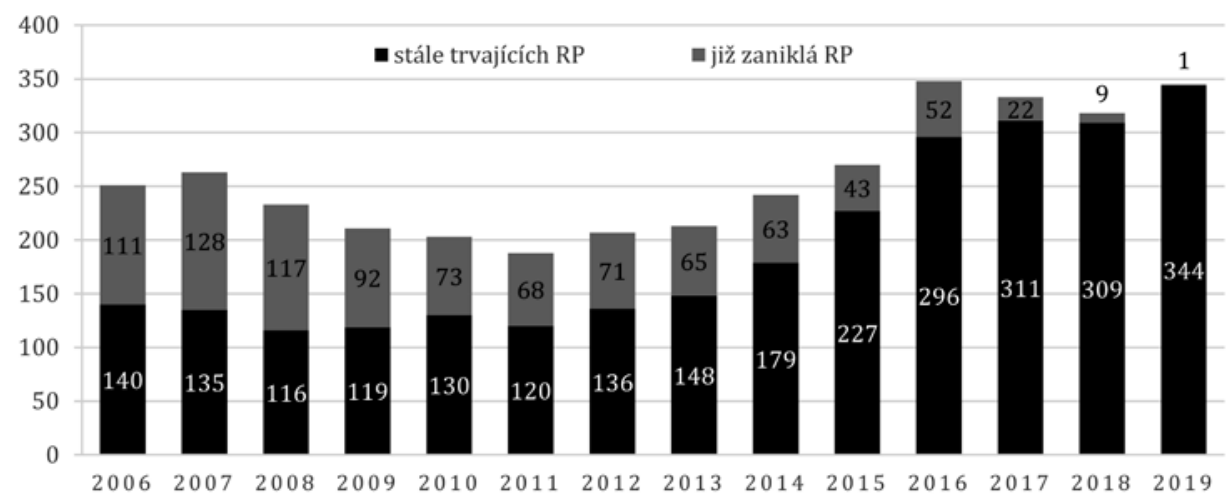

Zdroj: MV ČR, vlastní zpracování.

Pokud se zabýváme zánikem partnerství, tak z dat, která jsou k dispozici, nevíme, jestli byla partnerství zrušena z důvodu úmrtí, nebo z rozhodnutí partnerů či partnerek. Úmrtí partnera má v současné právní úpravě RP závažné ekonomické dopady. Jak úmrtí, tak i „rozvod" RP může způsobit právní, ekonomické, psychologické i společenské problémy obzvláště v prípadě, že jsou ve vztahu př́tomny nezletilé děti

\footnotetext{
13 Během ledna až dubna 2020 vstoupilo do RP podle dat MV ČR dalších 49 párů (29 mužských a 20 ženských).
} 
(více viz níže) (Kutálková 2015). Z dat také není možné vysledovat, jestli stejná osoba vstupuje do RP opakovaně s touž či jinou osobou. Víme tedy, že množství zrušených partnerství v dlouhodobém horizontu narůstá, což je ale logické, jelikož s délkou trvání a množstvím párů, které do RP vstoupily, stoupá i množství párů, které se mohou potenciálně rozpadnout.

Údaj, který se běžně uvádí u manželství, je doba, po jaké se vztahy rozpadají, a délka trvání rozvedených manželství. Podle Čsú ( $k$ 31. 12. 2018) se během prvního roku rozvedlo téměř $1 \%$ manželství, 17 \% trvalo jeden až čtyři roky, $21 \%$ se rozvedlo po pěti až devíti letech (akumulovaně jde o bezmála 40 \%) a zbývajících 61,8 \% po deseti či více letech (ČSÚ 2020c). Podíváme-li se podrobněji na data o ukončených RP $(n=915)$, vidíme obrázek poměrně odlišný. Během prvního roku trvání zaniklo přes $8,5 \%$, jeden až čtyři roky spolu žila téměř polovina a pět až devět let přetrvávala více než třetina zrušených RP. Zde je ovšem třeba upozornit na to, že i ta nejdelší RP mohou dosahovat délky pouze 14 let - dobu, kdy je možné v Česku do RP vůbec vstupovat. Zároveň musíme mít na paměti, že nevíme, co je důvodem zrušení RP, jestli úmrtí, nebo „rozvod”.

Graf 3: Zrušená RP podle délky trvání (k 31. 12. 2019)

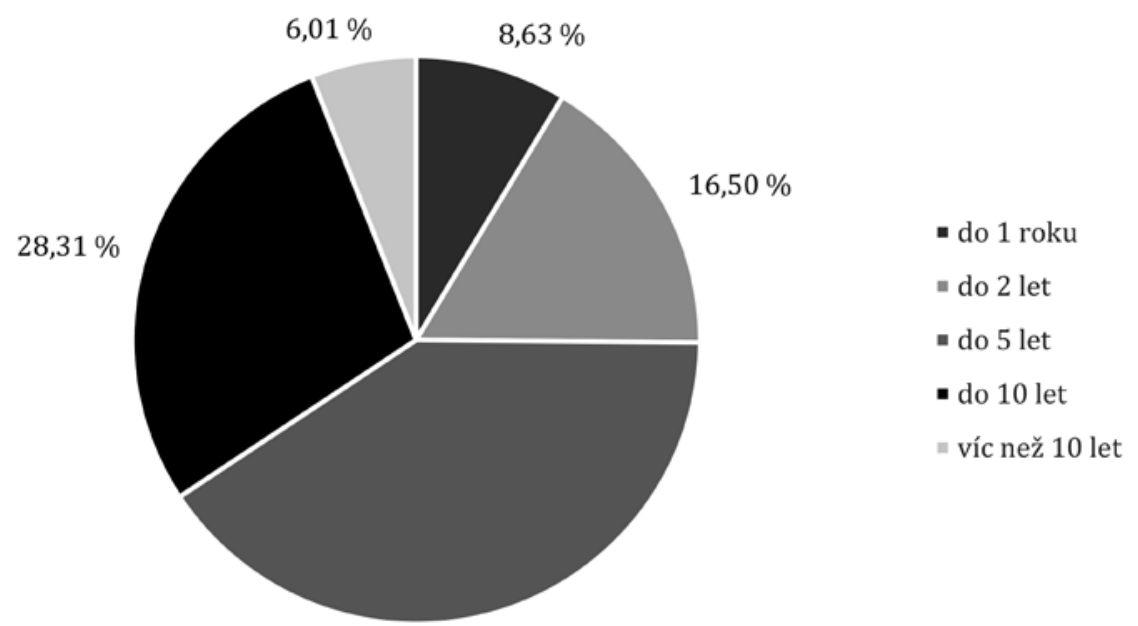

$40,55 \%$

Zdroj: MV ČR, vlastní zpracování.

Které faktory se podílejí na zániku registrovaných partnerství? $\vee$ tabulce 1 jsou prezentovány výsledky binární logistické regrese, $v$ níž je závisle proměnnou rozpad partnerství. Predikována je situace, že se partnerství rozpadne. Vstupní data 


\section{NV STATI / ARTICLES}

jsou bohužel velmi strohá na informace, ale výsledky ukazují, že všechny tři sledované faktory (pohlaví páru, věkový rozdíl mezi partnery či partnerkami i délka trvání vztahu) mají statisticky významný vliv na rozpad partnerství. Koeficienty naznačují, že partnerství mužů mají téměř o 30 \% nižší pravděpodobnost, že se rozpadnou, čím větší je věkový rozdíl mezi partnery nebo partnerkami, tím vyšší je možnost, že se partnerství rozpadnou, s rostoucí délkou partnerství ale pravděpodobnost rozpadu partnerství nepatrně klesá. Zdá se tedy, že stabilnější jsou partnerství mužů, partnerství věkově homogennější a partnerství, která již překlenula možné počáteční krize.

Tabulka 1: Významnost vlivu různých proměnných na zánik RP (binární logistická regrese)

\begin{tabular}{ll|l} 
& Sig. & $\left.\operatorname{Exp}(\mathrm{B})^{\star}\right)$ \\
\hline $\begin{array}{l}\text { Gender páru (mužský) } \\
\text { Věkový rozdíl v letech }\end{array}$ & 0,000 & $0,726^{* * *}$ \\
$\begin{array}{l}\text { Délka trvání v letech } \\
\text { Konstanta }\end{array}$ & 0,019 & $1,014^{\star}$ \\
\hline
\end{tabular}

\footnotetext{
*) Poznámka: * $p<0,05$; ** $p<0,01$; ** $p=0,00$. Charakteristiky modelů: Chí kvadrát test je statisticky signifikantní, Nagelkerkeho $R^{2}=0,03$

Zdroj: MV ČR, vlastní zpracování.
}

\section{Genderové souvislosti}

Gender je všeobecně velice významnou, ne-li klíčovou kategorií ve vztahu k partnerství. Obzvláště to platí pro páry stejného pohlaví, které otevírají prostor pro jiný pohled na heteronormativitu partnerství. Jak jsme již výše uvedli, gender páru je také nejsilnější proměnnou strukturující registrované partnerství. 
Graf 4: Gender párů vstupujících do RP

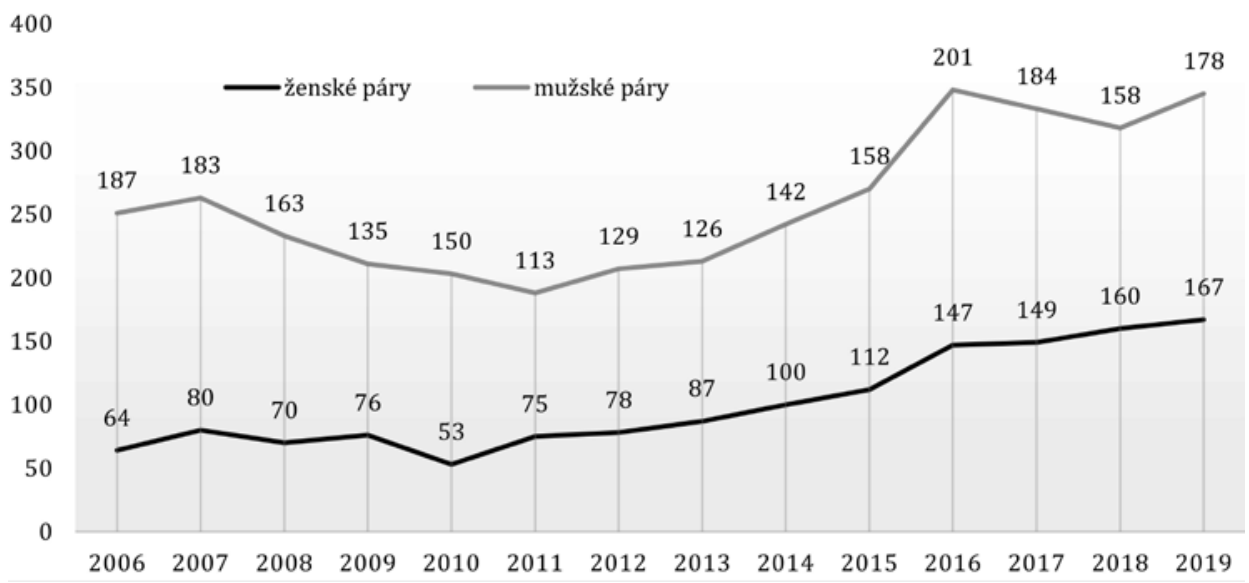

Zdroj: MV ČR, vlastní zpracování.

Zatímco prvních pět let tvořily až dvě třetiny nových registrovaných partnerství muži, je možné od roku 2010 sledovat kontinuální narůstající zájem žen o tento institut, kdy v roce 2018 vstoupilo poprvé do RP více žen než mužů (160 : 158). Počet vstupujících ženských párů se mezi lety 2010 a 2019, tedy s nejnižším a nejvyšším počtem nově uzavřených RP ztrojnásobil. (Zatímco u mužů je rozdíl mezi nejméně vstoupivšími v roce 2011 a nejvíce v roce 2016 ani ne dvojnásobný.)

Graf 5: Poměr vznikajících mužských a ženských párů v jednotlivých letech

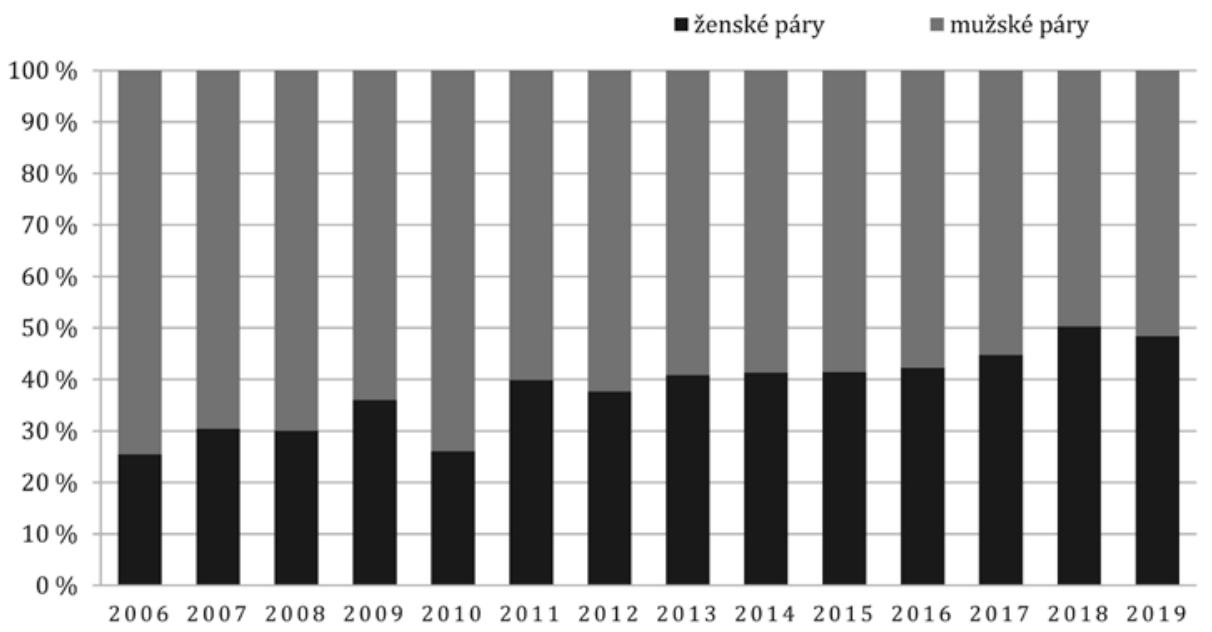

Zdroj: MV ČR, vlastní zpracování. 


\section{NV STATI / ARTICLES}

Otázkou je, jak interpretovat tato data. Hloubkové rozhovory realizované v rámci našeho výzkumu (viz níže část rodičovství) indikují změnu ve vnímání RP - jako institutu hlavně pro gaye a jako institutu "nevlídného", či dokonce bránícího rodičovství, jak to již bylo tematizováno (Sloboda 2016; Hašková, Sloboda 2019). Institutem pro gaye byl proto, že vlastně až do príchodu organizace GL-liga v roce 2003 dominovali celému LGBT+ aktivismu muži, a proto i RP bylo medializováno tak, že o něj mají zájem především mužské páry. "Lesbická” či řekněme ženská témata se ve veřejném diskursu objevila až později, obzvláště v souvislosti s prvním průvodem hrdosti Queer Parade v Brně 2008 (Fojtová, Sokolová 2013; Nedbálková 2016). Je tedy možné uvažovat o tom, že ženské páry začaly prijímat institut „za svưj” až poté. Výrazný vzestup zájmu v letech 2016 a 2017 bychom mohli interpretovat tím, že v roce 2013, resp. 2014 byl do Poslanecké sněmovny PČR předložen návrh novely registrovaného partnerství, který měl umožnit tzv. přiosvojení, což je obzvláště relevantní pro lesbické páry. Ty mají častěji děti plánované prímo do homopáru. Případná novela by umožnila do rodného listu zapsat partnerku, sociální matku. Zároveň s tím v roce 2016 Ústavní soud zrušil zákaz adopce pro jedince $v$ RP. Tím se stal institut RP rodičovsky přátelštější, a tím otevřenější homonormativitě.

Graf 6: Rozpad registrovaných partnerství podle délky trvání (v letech) a genderu

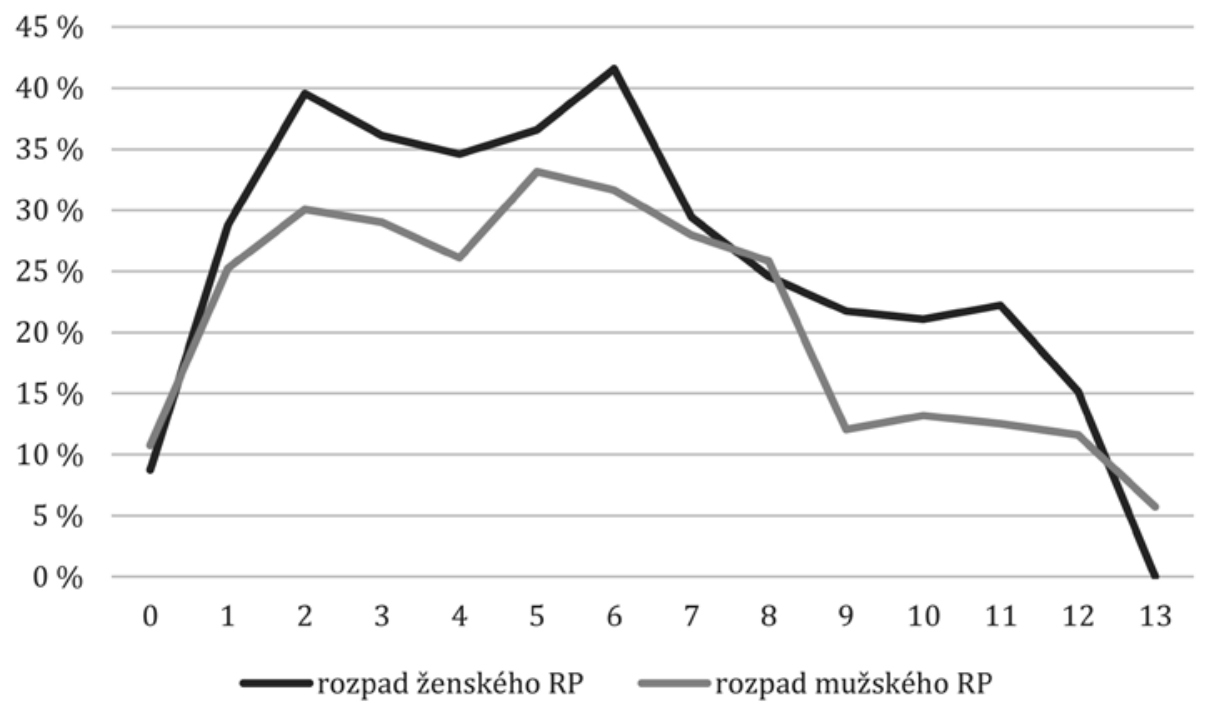

Zdroj: MV ČR, vlastní zpracování. 
Mužské a ženské páry v zásadě zanikají po celou dobu zhruba ve stejném poměru, nicméně analýza významnosti ukázala (viz tabulku 1), že muži mají o téměř 30 \% nižší pravděpodobnost, že se rozejdou. Ženy se rozcházejí obzvláště ve druhém a ještě častěji v šestém roce trvání partnerství. Rozcházejí se běžněji než muži i po delším vztahu (graf 6). Tento jev se nám může zdát překvapivý, jelikož ve společnosti jsou zakořeněny představy o mužské homosexualitě, jež předpokládají nestálejší vztahy, menší ochotu se vázat a větší míru konzumace sexu i vztahů. O lesbických ženách se stereotypně tvrdí opak. Tyto ustálené představy o homosexuálních mužích, produkované heteronormativitou (viz Fafejta 2014), data nepotvrzují, alespoň tedy pro značnou část mužů, kteří do RP vstupují. Musíme si také uvědomit, že pokud bychom znali počty gayư, leseb a bisexuálních žen a mužů v celé české populaci, jež by potenciálně mohli do RP vstoupit, bylo by možné stanovit relativní počty vstupujících a zanikajících partnerství, a tak data lépe interpretovat. Rovněž nemáme širší znalosti o očekáváních a motivacích pro vstup či důvody, proč vstupovat do RP v LGB populaci. Například při významně vyšším počtu gayů a bisexuálních mužů v populaci (než žen) bychom mohli zjistit, že vstupuje pouze malá, ale velice motivovaná skupina mužů sdílejících hodnoty stability a vázání se, jež je tudíž méně náchylná k rozchodu. Při nižším počtu lesbických a bisexuálních žen v populaci bychom pak možná mohli zjistit, že ženy do RP vstupují vlastně častěji a třeba impulzivněji, s méně jasnými očekáváními nebo po kratší známosti - na což by mohl poukazovat nižší průměrný věk ženských párư při vstupu (viz níže) -, a tak vytvářejí méně stabilní páry. Taková data k dispozici nejsou a získání dat na reprezentativním vzorku $L G(B)$ populace je velice problematické, jelikož jde o tzv. neviditelnou sociální skupinu. (Diskusi o tomto problému viz Vohlídalová, Maříková v prrípravě.) Rozsáhlejší studie o důvodech vstupu do RP a důvodech pro jeho ukončení by byla pro lepší pochopení tohoto fenoménu potřeba.

\section{Věkové souvislosti}

Ač existují osoby, jež vstoupily do RP již ve svých 18 letech, průměrným věkem vstupu je 36 let (u mužů 37, u žen 33 let). Nejstaršímu muži, který vstoupil do RP, bylo 87 let a nejstarší ženě 81.

Pokud se zaměříme na průměrný věk vstupu do RP v jednotlivých letech, vidíme poměrně stabilní křivku s výkyvem v prvním roce existence RP, tedy v roce 2006 . Pro tento rok můžeme pracovat s předpokladem, že vzhledem $k$ absenci tohoto institutu před tím budou masivně vstupovat do RP osoby všech generací, tedy významněji i těch starších, které na uzákonění léta čekaly. Přesto rozdíl není nijak zásadní. Prưměrný věk vstupu v roce 2006 činil 38,65 let, v dalším roce poklesl na 36,4 let, následně ještě o další rok. Od té doby se průměrný věk vstupu do RP drží na úrovni mezi 35 a 36 lety věku. 


\section{NV STATI / ARTICLES}

Graf 7: Průměrný věk při vstupu do RP v jednotlivých letech

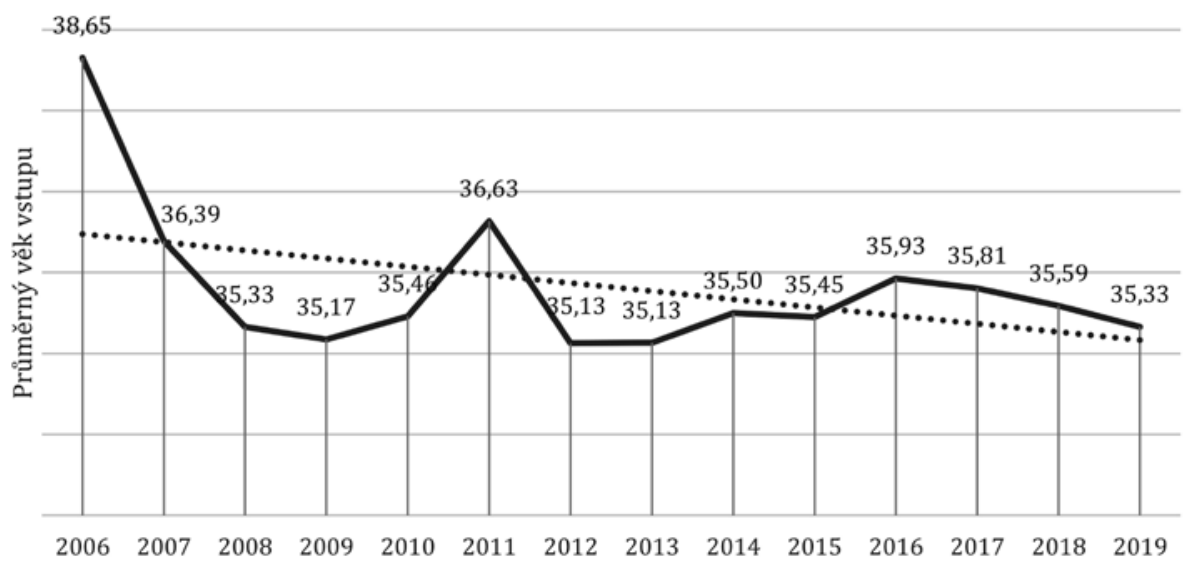

Zdroj: MV ČR, vlastní zpracování.

Zajímavé srovnání je ovšem se vstupem do manželství. Do něj muži vstupují ve 32 a ženy v nedovršených 30 letech - jde tedy v průměru o tři roky méně. Zároveň průměrný věk mužú je zhruba o tři roky vyšší než žen, a to jak u vstupujících do manželství, tak i do RP. Zároveň zatímco průměrný věk vstupu do RP se za posledních 14 let př́liš nemění, u heterosexuálních párů kontinuálně roste - mezi lety 2005 a 2017 o dva a půl roku (ČSú 2020b). Otevírá se tím prostor pro různé interpretace. Uzavření RP se podle našich hloubkových rozhovorů zdá být aktem vyzrálé volby. Vliv může mít to, že si gayové a lesby nacházejí stabilní partnery či partnerky teprve ve vyšším věku. Je to možná také projev určité fáze gay či lesbické identity, kdy jsou páry ochotny se nechat veřejně "označkovat".

Při větší miře sociologické imaginace bychom mohli uvažovat o hypotéze, že pokud by manželství v současné pozdně moderní společnosti stále ztrácelo svou hodnotu vlivem sociálních dynamik, jako jsou (a) sledování kariéry po určitou dobu po absolvování školy před vstupem do institucionalizovaného partnerství (např. Hasmanová Marhánková, Kreidl 2012), (b) větší komplikovanost současné postmoderní společnosti v hledání si stabilních partnerství (např. Beck, Beck-Gernsheim 2004; Stacey 1996), (c) „usazování se" teprve ve chvíli, kdy mají jedinci vyřešené bytové podmínky (Hašková 2014), (d) zásadní zeslábnutí imperativu institucionalizovaného uznání partnerského vztahu pro realizaci rodičovství (mj. Sobotka 2015), (e) rostoucí míra rození dětí mimo sezdaná soužití v ČR na úrovni blížící se 50 \% (ČSú 2020a), mohl by se ustálit věk vstupu do manželství na úrovni věku vstupu do RP, jenž je právě takovým institutem - se slabou symbolickou hodnotou, poskytující malé materiální zajištění a téměř žádné rodičovské zajištění. 
Graf 8: Relativní počty mužů a žen podle věku při vstupu do RP

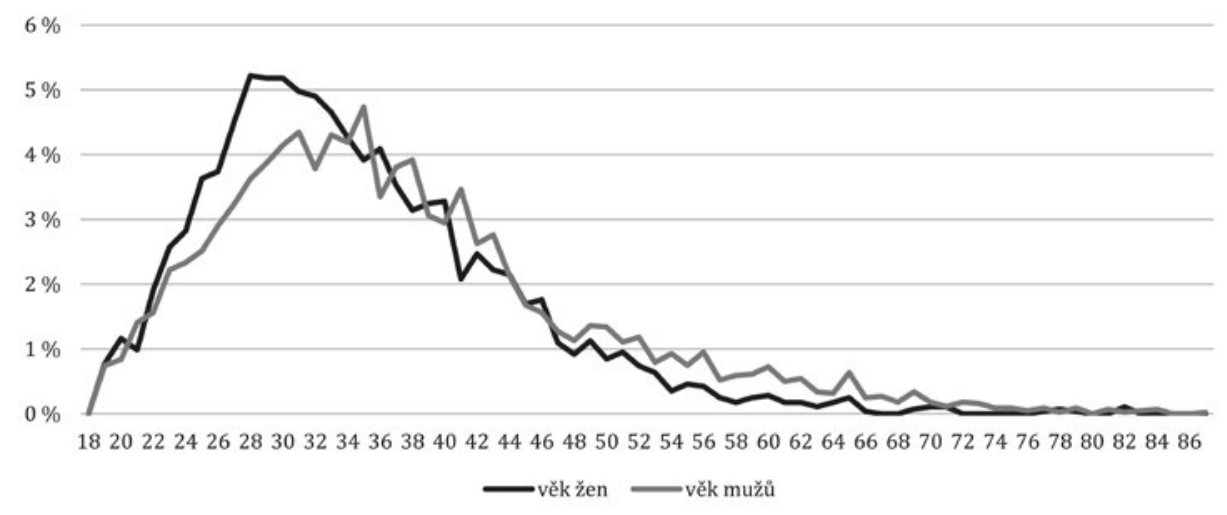

Zdroj: MV ČR, vlastní zpracování.

$\vee$ grafu 8 je patrno několik dílčích rozdílü. Ženy vstupují do vztahu zpravidla mladší - průměrný věk je 33 , zatímco u mužů 37 . Zároveň jsou mezi nimi v průměru menší věkové rozdíly - průměrný věkový rozdíl u žen je zhruba 5,5 roku, zatímco u mužů je průměrný rozdíl věku při vstupu do RP téměř osm let. Do RP vstupují skoro v polovině případů vrstevníci, jejichž věkový rozdíl činí nejvýš pět let (viz graf 9). Vůbec nejčastějším věkovým rozdílem jsou dva a tři roky. Věkový rozdíl do deseti let mají více než tři čtvrtiny nově uzavíraných partnerství. Rozdíl mezi partnery či partnerkami při vstupu do RP na úrovni 20 let a vyšší bylo možné pozorovat u téměř $6 \%$.

Když se zaměříme na rozdíly ve věku u mužsko-ženských párů vstupujících do manželství, ukazuje se nám trochu jiná struktura - vrstevníků (do pěti let) věku je výrazná polovina. Do deseti let rozdílu ve věku má téměř 80 \% vznikajících manželství a rozdíl vyšší 20 let se vyskytuje jen u 1,3 \% novomanželů (Čsú 2019). Jak bychom to mohli interpretovat? 


\section{NV STATI / ARTICLES}

Graf 9: Věkový rozdíl vstupujících do RP ( $k$ 31. 12. 2019) a manželství (k 31. 12. 2018)

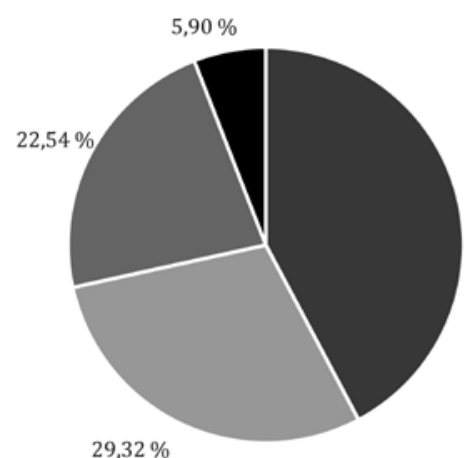

$29,32 \%$
$42,23 \%$

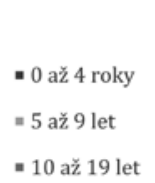

- 20 a více let

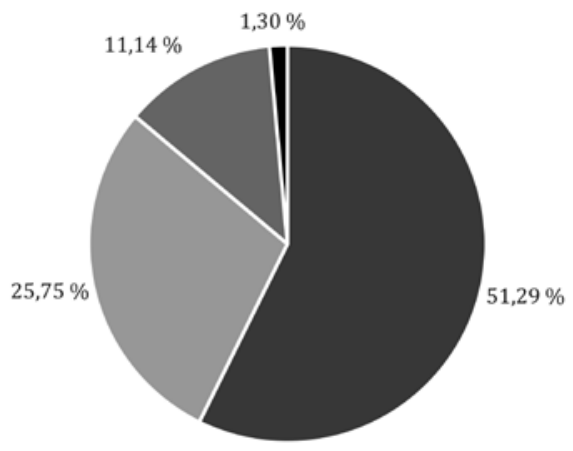

Zdroj: MV ČR a ČSÚ, vlastní zpracování.

Jedno z možných vysvětlení tohoto rozdílu souvisí s principem genderové polarizace v heteronormativním prostředí. Absence genderové dělby rolí u homopárů má za důsledek bud' větší rovnostářství, nebo výraznější nutnost vyjednávání. Toho si ve vztahu k rodičovství na základě hloubkových rozhovorů s lesbickými páry všímají např́iklad Kateřina Nedbálková (2011) a Petra Kutálková (2015). U některých svých informantek nacházejí myšlenku, že někdy by nerovnost a jednoznačnost rolí plynoucí z genderu byla ve vztahu výhodou, protože by nevyvíjela tlak na neustálé vyjednávání. Nabízí se nám tak hypotéza, že věková rozdílnost může produkovat obdobný typ „přirozené" dělby rolí mezi partnery či partnerkami stejného pohlaví. To by mohla nejspiše potvrzovat větší věková rozdílnost u mužských párů, pokud maskulinita je tou, která je ve společnosti vnímána jako dominantní a předpokládá partnera (resp. partnerku) v mocensky slabším postavení (srov. např. Connell 1987; Kimmel 2003). Důvod větších věkových rozdílů by mohl být zpưsoben také místy, kde je možné potkat potenciální partnery či partnerky. Gayové a lesby se často setkávají on-line, případně ve specifických klubech a podnicích, kde je zpravidla větší věková heterogenita. Opět by tedy šlo o důvody vyplývající z heteronomativity prostředí. Nicméně hlubší analýza a původní výzkumná data by byla potřebná k potvrzení takové hypotézy.

Posledním jevem, kterým se budeme v této části zabývat, bude věkové rozložení existujicích registrovaných partnerství ke konci roku 2019 (nikoliv při vstupu do RP). Průměrný věk osob v RP činí 41 let. Nejstarším žijícím registrovaným párem (uzavřeným v roce 2006 RP) je ženský pár ve věku 94 a 90 let. Podíváme-li se na věkovou strukturu v grafu 10, tak je možné sledovat obdobnou proporcionalitu jako v manželství ve věkové skupině od 18 do zhruba 50 let. Vidíme ale významně nižší zastoupení věkových skupin nad 50 let oproti manželství. 
Graf 10: Věková struktura žen a mužů v registrovaných partnerstvích (vlevo, k 31. 12. 2019) a v manželství (vpravo, k 31. 12. 2018)
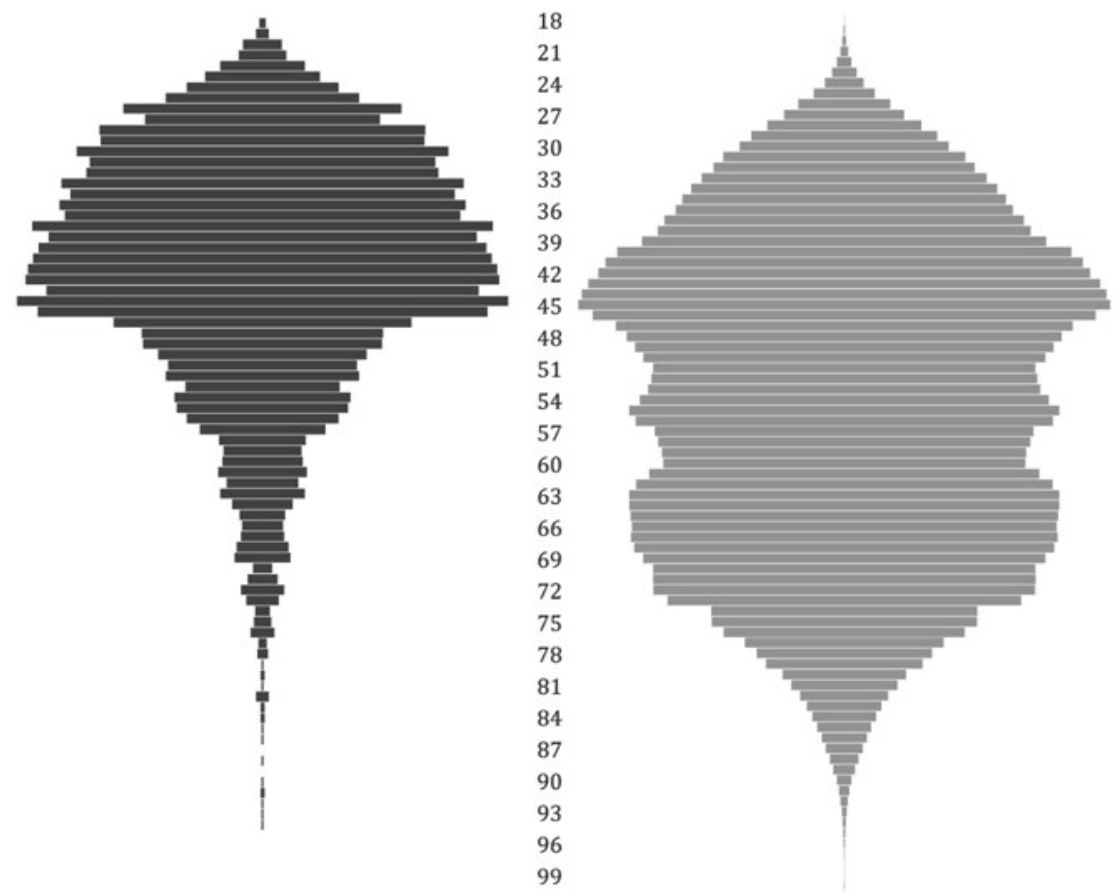

Zdroj: MV ČR a ČSÚ, vlastní zpracování.

Co je na této věkové struktuře RP a na porovnání s manželstvím zajímavé? Ukazuje se, že právní uznání partnerství nevedlo ke vstupu většího počtu párů do RP, obzvláště starší generace, přestože by mohlo naplnit touhu po právním uznání vztahu, které nebylo do roku 2006 možné. Optikou heteronormativity to Ize vysvětlit tak, že vyšší ročníky se zkušeností s neviditelností, zásadně omezené možností se setkávat a navazovat společností respektované a dlouhodobé partnerské vztahy, a to jak před rokem 1989, tak do jisté míry i během 90. let 20. století (Seidl 2012; Sokolová 2012), neměly s kým vstupovat do registrovaného partnerství nebo nechtěly své vztahy takto zviditelňovat. To však neplatí pro manželství.

Srovnáním věkového rozložení, při současném přijetí předchozí teze o paralelnosti RP s manželstvím ve své selektivní podstatě, bychom také mohli vyslovit domněnku, že si jsou vstup do manželství a do RP v principu podobné. To by mohl být argument proti potřebě udržovat výlučnost manželství. Jedním dechem je ale nutno dodat, že nám v tomto ohledu chyběji další data, jako je místo a charakter bydliště, ekonomická či vzdělanostní situace. Ve Sčítání lidu v roce 2011 byl identifikován vyšší podíl vyso- 


\section{NV STATI / ARTICLES}

koškolsky vzdělaných v RP oproti celkové populaci (22,8 ku 13,8 \%) a zároveň nízký podíl osob se základním vzděláním $(9,2 \%)$, přičemž u deklarovaných nesezdaných (neregistrovaných) homopartnerství je podíl osob s nejvýše dosaženým základním vzděláním zásadně vyšší (20,3 \%), přičemž se „vzdělanostní struktura neodlišovala od celkové populace" (ČSÚ nedatováno/2014b). Potvrzuje to tezi o selektivní podstatě RP - zde coby "rozmaru” vzdělanějších. Další a aktuálnější data v této souvislosti jsou velmi potřebná.

\section{Homoparentalita a děti v homopárech}

Rodičovství je významnou deklarovanou životní hodnotou (Možný et al. 2008) a institucionalizovaný a legitimizovaný svazek je historicky vnímán jako důležitý předpoklad pro rodičovství. To se v poslední době významně proměňuje (viz např. Hašková, Pospíšilová 2020; Sobotka 2015).

Na rozdíl od mužsko-ženských párů se homopáry mohou stát rodiči složitěji: bud' jeden nebo jedna z nich (či oba/obě) přichází do vztahu s dětmi z předchozích vztahů, nebo je dítě svěřeno do péče formou adopce či pěstounství, nebo - a to v posledních několika letech nejspíše představuje nejčastější způsob - se děti rodí plánovaně již do domácností párů stejného pohlaví (Kutálková 2015; Nešporová 2021). Zároveň jejich cesty k rodičovství častěji předpokládají zásadní plánovanost (Polášková 2009), ochotu „ohýbat" heteronormativitu a genderovanost prostředí, i tu vlastní (Nedbálková 2011), a užívat různé formy zprostředkované reprodukce (Hašková, Sloboda 2019; Turčan et al. 2020). At' je způsob vzniku rodičovství jakýkoliv, faktem je, že gayové, lesby a homopáry rodiči byli, jsou a budou, bez ohledu na kvalitu právního ukotvení nebo komplikovanost uskutečnění rodičovských tužeb.

Určit počet dětí všech gayů a leseb a specificky těch, které žijí v rodinách homopárů, je poměrně složité. Především proto, že naprostá většina dětí žije v rodinách mimo registrovaná soužití, zatímco $v$ rodinách heterosexuálních párů se stále nejméně polovina dětí rodí do manželství (Čsú 2020a).

Podle dat ze Sčítání lidu v roce 2011 žilo v domácnostech registrovaných partnerů či partnerek 46 závislých dětí (ekonomicky neaktivních do 26 let věku) ze všech 925 dětí žijících v domácnostech vedených párem stejného pohlaví. Zatímco neregistrovaných (faktických) homopartnerství bylo nejméně čtyřnásobně více než těch registrovaných, dětí žijících v domácnostech neregistrovaných partnerství je až $19 \mathrm{krát} \mathrm{více.} \mathrm{To}$ významně poukazuje na to, že RP není svazek, ve kterém by homopáry vychovávaly své děti. RP tak rozhodně neplní stabilizační funkci a spiše se tedy jeví jako nepřátelské rodičovství (Sloboda 2016). Od roku 2011 se situace samozřejmě poněkud proměnila a kvůli značnému nárůstu zájmu o RP obzvláště ženských párů je možné uvažovat o změně takového vnímání RP. Platí to ale jen za předpokladu, že by se do (či krátce 
před vznikem) RP $\vee$ posledních letech rodily děti více než $v$ době před téměř deseti lety. $Z$ dostupných dat to ale nelze prokázat.

Podle dat Ministerstva vnitra měly osoby žijící v RP (k dubnu 2020) 524 dětí, z toho 34 se narodilo po vzniku RP, 206 dětí ze všech bylo nezletilých (1-18 let v době vzniku RP) a dalších 122 bylo do věku 26 let. Potenciálně mají osoby v registrovaném partnerství až 362 nezaopatřených dětí. $V$ tomto ohledu jsou poskytnutá data velmi nekonkrétní, a tak není možné odhadnout, kolik z těchto 362 dětí žije v domácnostech homopárů. ${ }^{14}$ Dále ani data ze Sčítání lidu, ani data MV nepostihnou mnohé prípady rodičovství, jako je typicky sdílené rodičovství jednoho muže (např. gaye či heterosexuála) a jedné ženy (lesbické či heterosexuální), kteří spolu nežijí a ani jeden z nich není v RP nebo $v$ domácnosti vedené párem stejného pohlaví. Tato podoba sdíleného rodičovství se pak ve statistikách projeví jako nesezdaný a nekohabitující pár muže a ženy, zdánlivě tedy heterosexuální, mající dítě či děti (např. ve střídavé péči). Slepota dat vůči neheteronormativním formám rodičovství a partnerství je v tomto ohledu obzvláště markantní.

Reálný počet dětí je ale rozhodně vyšší, a to z důvodu vysoké míry neviditelnosti - jak pro statistiky, tak i kvưli skrývání v běžném životě. Vyšší počet dětí v homoparentálních rodinách oproti Sčitání lidu v roce 2011 Ize předpokládat také z důvodu proměny společenské situace $v$ následujících letech.

Z výzkumu české LGB populace (Maříková, Vohlídalová 2019) vyplývá, že rodičovství je důležité pro osoby s bisexuální identitou, obzvláště ženy (45 \% mužů a 69 \% žen), jež se tak přiliš neliší od heterosexuální populace. Méně často touží po dítěti lesby (24 \%), a ještě méně gayové (8 \%). Řada respondentů tohoto výzkumu uvedla, že žije se svými dětmi ve společné domácnosti nebo že s nimi jejich děti pobývají ve společné domácnosti občas. Podle dat z tohoto šetření jde primárně o děti počaté v dřivějším heterosexuálním vztahu. Dále se v tomto výzkumu ukázalo, že vedle běžných a očekávaných aspektů, jako jsou ekonomické či pracovní podmínky pro realizaci rodičovství, jsou významnou bariérou v rodičovství aspekty související s heteronormativitou prostředí. Ač je aspekt partnerství zásadní rovněž pro hetero populaci, specifičnost tkví v omezené možnosti výběru a nalezení partnera či partnerky stejného pohlaví. A obzvláště pak nalezení takové(ho), která/který by chtěl(a) mít dítě také. Pro prípadnou realizaci rodičovství je často významná rovněž existence nebo absence sociální podpůrné sítě (např. prarodiče), jež nestigmatizuje, ale respektuje homoparentální model rodičovství. Jako obzvláště významná bariéra se ukazuje ztížená možnost reálně biologicky dítě počít nebo právně získat (tamtéž.). Oba aspekty jsou často silně provázané.

${ }_{14}$ Kvưli důsledné anonymizaci dat ministerstvem se nám podařilo vztah dětí k pohlaví/genderu nebo věku rodičů zrekonstruovat pouze u 2333 z 2749 párů existujících ke konci dubna 2020. 


\section{Ambivalentní registrované partnerství a homoparentalita}

Podíváme-li se na homoparentalitu v souvislosti s RP, je možné na základě poznatků z vlastního kvalitativního výzkumu postulovat značnou ambivalentnost tohoto institutu.

Sice zřídka, ale Ize se setkat s pozitivním, individuálním a hodnotovým pohledem na RP před samotným rodičovstvím. Jak naznačuje Zuzana, může jít např. o deklaraci pro širší rodinu:

Tak nějak jsme chtěly s partnerkou ukázat i okolí $i$ všem, její rodině, že vlastně to myslíme vážně, že to není jenom nějaké takové soužití a pak se uvidí, takže fakt jsme chtěly to tak nějak jakože spojit dohromady a splnit si to. (Alžběta, 41 let, lesba, registrovaná, rodič)

Často obzvláště ženské páry až poté, když reálně začnou řešit cesty k rodičovství, zjištují, že si některé možnosti vstupem do RP uzavřely nebo zkomplikovaly. RP může naprríklad přinášet nežádoucí coming-out při využití asistované reprodukce ve zdravotnickém zařízení.

Začaly jsme zjištovat, jak to u nás funguje, že vlastně nemůžeme za ruku nakráčet na nějakou kliniku, aby nám dali sperma a podobný věci. Takže jsme i na základě toho v podstatě řešily registraci, nebo neregistraci. My jsme sice měly jakoby svatbu, jako na oko, bez jakýchkoliv oficialit. V současný době nejsme registrovaný ještě pořád, právě kvůli tady tomu jako dítěti. (Radka, 34 let, lesba, zadaná, těhotná)

Radka tak uvádí hodnotovou potřebu určitého symbolického aktu, kterým ale RP být nemůže, jelikož vstup do něj by byl neinstrumentální. (Více o tomto fenoménu viz také Kutálková 2015; Hašková, Sloboda 2019; Nešporová 2021.)

Trochu jiná situace se ukázala v případě adopcí (typičtější pro mužské páry):

Sociální pracovnice se nás ptala, jestli jsme registrovaný, i když to nemá žádný vliv, a tak nějak naznačila, že by to mohlo mít výhody. Možná, že by ji to utvrdilo, že jsme stabilní pár. A my jsme jí řekli, že nejsme, a ona se neptala, jestli o to máme zájem. Ale řekli jsme jí, že máme zájem o manželství. (David, 27 let, gay, zadaný, nerodič)

Zde je vidět další zajímavý paradox RP. Na jedné straně je párová adopce právně zapovězena, a do roku 2016 byla zakázána i ta individuální, což vedlo k nevstupování 
do RP u těch, kteří chtěli adoptovat individuálně. Jsou známy prípady gayů a gay párů, jež chtěly (musely) adoptovat své neteře či synovce, což by jim bytí v RP znemožnilo. Na straně druhé při adopčním řízení bude vždy posuzován i partner či partnerka uchazeče nebo uchazečky o adopci, a tak bytí v RP může být deklarací stability páru a pozitivním aspektem $v$ samotném řízení.

Homopáry nahližely na RP instrumentálně i v situaci již realizovaného rodičovství. Někdy jej vnímaly jako přípravu na prípadné právní ukotvení přiosvojení - jakmile to bude možné -, nebo jako stabilizaci vztahu, i s dětmi. Vstup do RP sice neumožňuje automatickou změnu príimení, ale je jednoznačným důvodem pro souhlas matriky při jeho změně. Přijetí stejných příjmení všemi členy nebo členkami rodiny bylo také používáno jako nástroj pro predcházení homofobnímu jednání vưči rodině nebo případným životním komplikacím. Toto například uvedli v souvislosti s letem do ciziny Dalibor s Filipem, kteří mají dvě děti, prričemž každý je biologickým rodičem jen jednoho, „ale tím, že jsme si vzali stejný jméno, tím je to jednoduššl." (Filip a Dalibor, 30 a 38 let, registrovaní, sociální i biologičtí rodiče)

RP tak může pomoci při realizaci rodičovství, na stranu druhou jej ale zviditelňuje a tím zvyšuje tlak na coming-out homopáru, což nebývá žádoucí pro ty partner(k)y, kteří/které chtěji být spíše neviditelní/neviditelné a tím svou rodinu chránit (viz také Kutálková 2015). Záleží ale na hodnotové orientaci a sociální situaci konkrétní osoby či páru. Pro Alžbětu byl coming-out jejího partnerství samozřejmý i při informování školky, kdo bude vyzvedávat dítě:

Já vlastně do závorky vždycky připisuju partnerka nebo registrovaná partnerka a nikdo to nijak neřeší. Není tam napsané, že by to byla nějaká teta, jako pokrevní, spiš tam mám napsáno registrovaná partnerka. (Alžběta, 41 let, lesba, registrovaná, rodič)

Přesto je absence institutu, který by právní vztah mezi dětmi a sociálními rodiči vytvořil, tak jako je to v manželství a jako by to mohlo platit pro přiosvojení v RP, vnímána jako důležitá a je netrpělivě očekávána.

My jsme se registrovaly, chtěly jsme. Hned, jak se to uzákonilo (...), že člověk má $\checkmark$ uvozovkách nějaký papír. A i kvůli tomu zjištění zdravotního stavu v nemocnici nebo kvůli nějakým základním právním úkonưm, který jsou pak jednodušší. [Ale] od té doby, co máme děti, tak je to pro nás nevyhnutelný mit svatbu. (...) Naštěstí máme úžasnýho pediatra, když já tam jdu s Anetkou, tak v pohodě, on mi všechno řekne, já ji tam mưžu odvést. Ale k jinýmu specialistovi už musi partnerka. Takže vzhledem k právům na děti. Ještě když jich máme tolik. (Vlasta, 35 let, lesba, registrovaná, sociální i biologický rodič) 


\section{STATI / ARTICLES}

\section{Závěr}

Tato stat' přináší v českém odborném diskursu ojedinělý obraz partnerství párů stejného pohlaví, především $v$ institucionalizované podobě $-v$ registrovaném partnerství. Kombinuje mnoho dílčích dostupných sociologických a statistických dat, data specificky poskytnutá Ministerstvem vnitra i data z původního kvantitativního a kvalitativního výzkumu. Tím je zkonstruován dosud absentující a i přes omezenou vypovídací schopnost dat neustrojených pro sociologickou analýzu poměrně komplexní obraz RP a jeho téměř 15letého vývoje. Přezíravý př́stup nejvyšší státní autority (ČSú) zveřejňující informace o obyvatelstvu, ale ne o RP, je možné interpretovat jako projev institucionalizované heteronormativity.

Na základě naší analýzy vykazují (registrovaná) homopartnerství několik charakteristik: (1) rostoucí, ale selektivní, (2) genderovaný, (3) manželství (ne)podobný a (4) rodičovství (ne)prátelský.

1. Z dat je patrné, že se počet RP postupně zvyšuje, obzvláště od roku 2016. Nárůst je způsoben nejspíše tím, že si společnost na institut již zvykla a vnímá jej jako žádoucí. Zároveň do něj začalo vstupovat významně více ženských párů než na začátku. Přestože nemáme přesná data o množství gayư a leseb v české populaci, množství homopárů žijících mimo RP a obzvláště těch, které vychovávají děti, poukazuje na to, že RP není masovým a oblíbeným institutem, mj. do RP vstupují častěji lidé s vyšším vzděláním.

Jelikož bychom mohli institut RP považovat za institut "na půl cesty" k manželství (mj. Burešová 2020; Vráblíková 2006), nabízí se v dalších analýzách rozšíriit srovnávání RP a neregistrovaných homopárů s nesezdanými heteropáry. Systematická data o kohabitujících homopárech, kterých je násobně více než těch v RP, však chybějí zcela.

2. V posledních šesti letech výrazně stouplo množství ženských párů vstupujících do RP a nyní tvoří téměř polovinu. To naznačuje posun v chápání RP jako institutu nejen pro gaye. Ženy vstupují do RP obdobně jako u manželství mladší (zhruba o tři roky). Ovšem oproti stereotypní představě o nestabilní gay identitě regresní analýza ukázala, že mužské páry mají téměř o 30 \% nižší pravděpodobnost, že se rozpadnou. Více dalších socioekonomických dat a informací o motivaci pro vstup do RP by bylo potřeba pro detailnější vysvětlení tohoto jevu.

$\checkmark$ textu jsme na základě analýzy věkových rozdílů vstupu do RP, které jsou oproti manželství vyšší a častější, obzvláště u mužůn, nabídli hypotézu k budoucímu ověření, že coby důsledek heteronormativity může věková nerovnost u určité skupiny párů nahrazovat nerovnost genderovou, jež je apriorně př́tomná u heterosexuálních párů. $\mathrm{K}$ tomuto by ale byla opět žádoucí hlubší analýza.

3. Registrované partnerství vykazuje mnoho podobností, ale i odlišností od manžel- 
ství. Mezi zajímavé podobnosti jistě patří podíl zaniklých RP uzavřených v prvních pěti letech existence tohoto institutu. Nutno ale podotknout, že neznáme důvody zániku a neumíme odlišit zánik úmrtím a "rozvodem". V datech jsme také pozorovali výkyv v počtu uzavřených RP s minimem v roce 2011, jenž je podobný výkyvu u vstupu do manželství a může být vysvětlen coby důsledek ekonomické krize z let 2008 a 2009. Nabízí se ovšem také vysvětlení ze zklamání z nedostatečnosti RP, které mělo podle některých autorek (Fojtová, Sokolová 2013; Nedbálková 2016) za následek restart aktivismu s hlavními tématy rodičovství a manželství. Obdobně jako u manželství jsou muži při vstupu do RP v průměru o tři roky starší než ženy. Podobné je také věkové rozložení osob v RP do 50 let věku.

Naproti tomu osoby vstupující do RP jsou v prưměru o tři roky starší (ovšem věkový trend vstupu do manželství je rostoucí a potenciálně se bliží věkové hranici RP). Věkové kohorty starší 50 let se nacházejí v RP jen minimálně. Oboje může být dưsledkem heteronormativity spojeným s obtížnějším nalezením partnera či partnerky ve vyšším věku nebo se snahou o neviditelnost homopáru, která je více vžita u starších gayů a leseb, aby se předcházelo prípadné homofobii okolí. Oproti manželství jsou lidé, obzvláště muži, v RP věkově heterogennější, což jako hypotézu pro další bádání spojujeme u určité skupiny homopárư s produkcí nerovnosti podobné tzv. tradiční (genderové) dělbě rolí u heteropárů. Zásadní odlišností RP od manželství je jeho ž̌ejmá selektivita - do RP vstupuje významně menší množství homopárư než heteropárů do manželství, a to i přesto, že „obliba" manželství za posledních několik dekád zásadně poklesla. Přesto je manželství referenčním rámcem nejen v naší analýze, ale i v samotném přemýšlení a hodnocení velké části gayů, leseb a obzvláště stabilních homopárů.

4. Zásadně odlišná je situace ve vztahu RP a rodičovství, prričemž analýza přinesla poměrně ambivalentní pohled. Je zřejmé, že pokud páry nevidí ve vstupu do RP určitou symbolickou hodnotu, tak rozhodně při zvažování svého rodičovství do RP nevstupují. Instrumentálně jim to ztěžuje přístup k IVF a až do roku 2016 i k adopci. Podle dat Ministerstva vnitra (z roku 2019) mají osoby v RP potenciálně až 362 závislých dětí. Podle Sčítání lidu z roku 2011 bylo v RP jen 46 závislých dětí ze všech 925 dětí žijících v deklarovaných homoparentálních domácnostech. Přesto někteří rodiče vstup do RP používají spíše jako symbolický stabilizační prvek - sobě i ostatním deklarují, že to myslí spolu vážně (projev homonormativity). Jiní rodiče svou registraci považují za potenciální nežádoucí coming-out celé rodiny. Všichni současní či plánující rodiče, kterých jsme se $v$ našem výzkumu dotazovali, ale uvedli, že by uvítali, či dokonce potřebují právní změnu (důsledek heteronormativity). Výjimkou jsou sdílená rodičovství např. lesbických matek či hetero matky a gay otců (konstelace dvou až čtyř rodičů). Tato forma homoparentality silně narušuje heteronormativitu a je zároveň pro dosavadní kvantitativní data prakticky neviditelná, jelikož se 


\section{NV STATI / ARTICLES}

v datech ukáže jako rodičovství nesezdaného (zpravidla nekohabitujícího) páru muže a ženy (heteropáru).

Strategií předcházení homofobii či některým každodenním problémům plynoucím z absentujících práv dětí vưči jejich sociálnímu rodiči je (v heteronormativní logice) přijetí stejného jména všemi členy nebo členkami rodiny. Paradoxně to ale RP (na rozdíl od manželství) neumožňuje automaticky.

Závěrem je nutné konstatovat, že tento text sice přináší značné množství informací o registrovaném partnerství a homoparentalitě, obrázek však zůstává nekompletní a mnoho otázek nezodpovězených. Naléhavý je proto požadavek na dostupnost komplexnějších zdrojů dat pro další analýzy.

\section{Literatura}

Beck, U., E. Beck-Gernsheim. 1995. The Normal Chaos of Love. New Jersey: Polity Press.

Beck, U., E. Beck-Gernsheim. 2004. Families in a Runaway World. Pp. 499-514 in J. Scott, J. Treas, M. Richards (eds.). The Blackwell Companion to the Sociology of Families. Malden, MA: Blackwell Publishing.

Burešová, K. 2020. Rodičovství a partnerství gayů a leseb v českém právu. Praha: Sociologický ústav AV ČR, v.v.i.

Castro Varela, M. d. M., N. Dhawan, A. Engel (eds.). 2016. Queer Interventions, Hegemony and Heteronormativity: Revisiting , the Political' in Queer Politics. London, New York: Routledge, Taylor \& Francis Group.

Connell, R. W. 1987. Gender and Power: Society, the Person, and Sexual Politics. Stanford: Stanford University Press.

CVVM. 2019. Postoje veřejnosti k právům homosexuálů - květen 2019. Praha: SOÚ AV ČR. Staženo 2. 2. 2020 (http://cvvm.soc.cas.cz/media/com_form2content/documents/c2/ a4940/f9/ov190607.pdf).

CVVM. 2020. Postoje českých občanů k partnerství, manželství a rodičovství -- únor 2020. Praha: SOÚ AV ČR. Staženo 25. 1. 2021 (https://cvvm.soc.cas.cz/media/com_ form2content/documents/c2/a5175/f9/ov200325.pdf).

Čsú. nedatováno/2014a. Nesezdaná soužití: hlavně ve velkých městech. Praha: Český statistický úřad. Staženo 25. 1. 2021 (https://www.czso.cz/csu/czso/a50041548c).

Čsú. nedatováno/2014b. Registrované partnerství je častější u mužů. Praha: Český statistický úřad. Staženo 25. 1. 2021 (https://www.czso.cz/csu/czso/0800492b9c).

ČSÚ. 2019. Demografická ročenka České republiky - 2018: B.12 Sňatky podle rozdilu věku snoubenců a rodinného stavu. Praha: Český statistický úřad. Staženo 21. 1. 2021 (https:// www.czso.cz/documents/10180/91917728/13006719rb12.pdf).

Čsú. 2020a. Demografická ročenka České republiky - 2019. Praha: Český statistický úřad. Staženo 25. 1. 2021 (https://www.czso.cz/documents/10180/121768536/13006720.pdf). 
ČSú. 2020b. Zaostřeno na ženy a muže - 2019: 1. Obyvatelstvo, rodiny, domácnosti - 14. Průměrný věk při uzavření prvního manželství, mezinárodní srovnání. Praha: Český statistický úřad. Staženo 21. 1. 2021 (https://www.czso.cz/ documents/10180/91605937/300002190114.pdf).

ČSú. 2020c. Zaostřeno na ženy a muže - 2019: 1. Obyvatelstvo, rodiny, domácnosti - 26. Rozvody podle délky trvání manželství ve vybraných letech. Praha: Český statistický úrad. Staženo 20. 1. 2021 (https://www.czso.cz/documents/10180/91605937/300002190126. pdf).

Duggan, L. 2002. The New Homonormativity. Pp. 175-94 in R. Castronovo, D. D. Nelson et al. (eds.) New Americanists, Materializing Democracy: Toward a Revitalized Cultural Politics. North Carolina: Duke University Press.

Fafejta, M. 2014. Sexuální scénáře v paradigmatické a postparadigmatické společnosti. Sociální studia / Social studies 11 (1): 153-171.

Fojtová, S., V. Sokolová. 2013. Strategies of Inclusion and Shifting Attitudes torwards Visibility in the Gay, Lesbian, and Queer Discourse in the Czech Republic after 1989. Pp. 105-129 in N. Fejes, A. P. Balogh, E. Fox, B. Ball (eds.). Queer Visibility in Post-socialist Cultures. Bristol England, Chicago Illinois: Intellect.

Foucault, M. 2000. Dohližet a trestat. Praha: Dauphin.

Gibbs, J. 1965. Norms: The Problem of Definition and Classification. American Journal of Sociology 7 (5): 586-594.

Giddens, A. 2012. Transformace intimity. Praha: Portál.

Guasti, P., L. Bustikova. 2020. In Europe's Closet: The Rights of Sexual Minorities in the Czech Republic and Slovakia. East European Politics 36 (2): 226-246, https://doi.org/10.1 080/21599165.2019.1705282.

Hasmanová Marhánková, J., M. Kreidl. 2012. Proměny partnerství: Životní dráhy a partnerství v české společnosti. Praha: Sociologické nakladatelství (SLON).

Hašková, H. 2009. Fenomén bezdětnosti. Praha: Sociologické nakladatelství (SLON).

Hašková, H. (ed.) 2014. Vlastní cestou?: Životni dráhy v pozdně moderní společnosti. Praha: Sociologické nakladatelství (SLON), Sociologický ústav AV ČR.

Hašková, H., Z. Sloboda. 2019. Negotiating Access to Assisted Reproduction Technologies in a Post-Socialist Heteronormative Context. Journal of International Women's Studies 20 (1): 53-67. Staženo 3. 3. 2019 (https://vc.bridgew.edu/jiws/vol20/iss1/5/).

Hašková, H., K. Pospíšilová. 2020. Kdo plánuje jedináčka a kdo chce zůstat bezdětný? Faktory ovlivňující nízké reprodukční plány mužů a žen. Czech Sociological Review 56 (2): 131-164, https://doi.org/10.13060/csr.2020.005.

Katz, J. N. 2007. The Invention of Heterosexuality. Chicago, IL: University of Chicago Press. Kimmel, M. S. 2003. Masculinity as Homophobia. Pp. 23-35 in E. Disch (ed.).

Reconstructing Gender. New York: McGraw Hill.

Kutálková, P. 2015. Duhové rodiny ve stínu státu: Situace homoparentálních rodin s malými dětmi. Praha: Prague Pride. Staženo 20. 1. 2021 (https://www.praguepride.cz/cs/mediadownload/publikace/12-duhove-rodiny-ve-stinu-statu/file). 


\section{NV STATI/ ARTICLES}

Maříková, H. 2009. Pečujíí otcové: Příběhy plné odlišností. Sociologický časopis / Czech Sociological Review 45 (1): 89-113.

Maříková, H., M. Vohlídalová. 2019. Bariéry versus preferované formy rodičovství u neheterosexuální populace. Fórum sociální politiky 13 (6): 20-26. Staženo 1. 2. 2021 (https://www.vupsv.cz/download/forum-socialni-politiky-62019/?wpdmdl=7611\&refresh=601778dbba5f71612151003).

Možný, I., P. Pakosta, M. Přidalová. 2008. Declining Fertility in Europe and What Parenthood Means to the Czechs. Brno: Masaryk University.

Nedbálková, K. 2011. Matky kuráže: Lesbické rodiny v pozdně moderni společnosti. Praha, Brno: Sociologické nakladatelství (SLON), Masarykova univerzita.

Nedbálková, K. 2016. Idle Ally: The LGBT Community in the Czech Republic. Pp. 205-221 in I. Jusová, J. Šiklová (eds.). Czech Feminisms: Perspectives on Gender in East Central Europe. Bloomington: Indiana University Press.

Nešporová, O. 2021. Homoparentální rodiny. Praha: VÚPSV, v.v.i.

Polášková, E. 2009. Plánovaná lesbická rodina: Kličové aspekty přechodu k rodičovství. Brno: Masarykova univerzita.

Prudký, L. a kol. 2009. Inventura hodnot. Praha: Academia.

Roseneil, S. 2007. Queer Individualization: The Transformation of Personal Life in the Early 21st Century. NORA - Nordic Journal of Feminist and Gender Research 15 (2-3): 84-99, https://doi.org/10.1080/08038740701482952.

Seidl, J. 2012. Od žaláře k oltári: Emancipace homosexuality v českých zemích od roku 1867 do současnosti. Brno: Host.

Slepičková, L. 2014. Diagnóza neplodnost: sociologický pohled na zkušenost nedobrovolné bezdětnosti. Praha: Sociologické nakladatelství (SLON).

Sloboda, Z. 2016. Dospivání, rodičovství a (homo)sexualita. Praha: Pasparta.

Sobotka, T. 2015. Low Fertility in Austria and the Czech Republic: Gradual Policy Adjustments. 2/2015. Vienna: Vienna Institute of Demography, Austrian Academy of Sciences. Staženo 1. 2. 2021 (https://www.econstor.eu/ bitstream/10419/110987/1/818640359.pdf).

Sokolová, V. 2009. Otec, otec a dítě: Gay muži a rodičovství. Sociologický časopis / Czech Sociological Review 45 (1): 115-145. Staženo 20. 1. 2021 (https://sreview.soc.cas.cz/pdfs/ csr/2009/01/06.pdf).

Sokolová, V. 2012. Skládání duhové mozaiky: Česká sexuologie a "gay" a "lesbická" orální historie v komunistickém Československu. Gender, rovné př́ležitosti, výzkum 13 (2): 28-39, https://www.genderonline.cz/ uploads/7c1f4772294a23329f9433e60e05c86247088d5c_sokolova-skladani-duhovemozaiky.pdf.

Stacey, J. 1996. In the Name of the Family: Rethinking Family Values in the Postmodern Age. Boston: Beacon Press.

Turčan, P., M. Procházka, P. Pokorný, J. Kvintová, M. Sigmund, E. S. Jurásková. 2020. „Desire for Parenthood and Associated Trends in Czech Lesbian Women." Sexual Medicine, 8 (4): 650-659, https://doi.org/10.1016/j.esxm.2020.08.004. 
Veřejný ochránce práv. 2019. Být LGBT+ v Česku: Zkušenosti LGBT+ lidí s předsudky, diskriminací, obtěžováním a násilím z nenávisti. Brno: Veřejný ochránce práv. Staženo 20. 1. 2021 (https://www.ochrance.cz/fileadmin/user_upload/DISKRIMINACE/Vyzkum/ Vyzkum-LGBT.pdf).

Vohlídalová, M., H. Maříková (v přípravě). Parenting Desires and Sexual Identities. Sociologický časopis / Czech Sociological Review.

Vráblíková, K. 2006. Gay a lesbické hnutí v České republice. Časopis pro politiku a mezinárodní vztahy. Staženo 21. 1. 2021 (http://www.globalpolitics.cz/studie/gaylesbicke-hnuti).

Warner, M. 1991. Introduction: Fear of a Queer Planet. Social Text (29): 3-17.

Weeks, J. 2000. Making Sexual History. Cambridge: Polity Press, Blackwell.

(c) BY-NC Zdeněk Sloboda, 2021.

(c) BY-NC Sociologický ústav AV ČR, v. v. i., 2021.

Mgr. Zdeněk Sloboda vystudoval mediální studia na FSV UK v Praze. Od roku 2011 působí jako asistent na katedře mediálních a kulturálních studií a žurnalistiky Filozofické fakulty Univerzity Palackého v Olomouci. Mimo jiné se dlouhodobě věnuje tématům sociologie genderu a sexualit. Působil jako výzkumník v Sociologickém ústavu AV ČR (2008-2009 a 2018-2020), kde se podílel na výzkumu homoparentality. Vydal knihu Dospívání, rodičovství a (homo)sexualita (2016, nakl. Pasparta) a je předsedou Výboru pro sexuální menšiny Rady vlády pro lidská práva. Kontaktní e-mail: zdenek.sloboda@gmail.com. 